\title{
Archetypes of common village pasture problems in the South Caucasus: insights from comparative case studies in Georgia and Azerbaijan
}

\author{
$\underline{\text { Regina Neudert }}^{1}, \underline{\text { Anja Salzer }}^{1}$, Naiba Allahverdiveva $^{2,3}$, Jonathan Etzold $^{1}$ and $^{\text {Volker Beckmann }}{ }^{1}$
}

\begin{abstract}
Complex social-ecological systems (SES), especially systems with common pool resources, often exhibit system dynamics characterized by emergence, where system properties cannot be fully explained by input variables. This causes challenges when it comes to explaining resource use problems because problem dynamics can differ from case to case despite similar input variables. Archetype analysis with its focus on identifying building blocks of nature-society relations might provide a means to tackle emergence and complexity in the analysis of resource use problems in SES. Using data from inter- and transdisciplinary research investigating comparative case studies on common village pasture management in the Caucasus region, we use the archetype approach with a focus on system archetypes that place particular emphasis on recognizing recurrent structures and internal dynamics. We apply three system archetypes, the Tragedy of the Commons, Shifting the Burden, and Success to the Successful, to different aspects of interlinked management problems that occur repeatedly in the case study data. Using SES variables characterizing the cases, we discuss variable combinations that may trigger specific dynamics. Moreover, we explore interlinkages between archetypical problems and discuss possible solutions based on self-governance. We find that the archetype approach with a focus on system archetypes resulted in consistent explanations of problem dynamics leading to important additional insights into root causes and internal archetypical dynamics compared with existing knowledge. Regarding problem solutions and policy recommendations, we show that viewing archetypical problems as interlinked in their actual case-study context leads to different recommendations than when each archetype is viewed on its own.
\end{abstract}

Key Words: archetypes; common management; common pool resources; comparative case studies; degradation; pasture; rangeland management; rangelands; system archetypes; system dynamics; Tragedy of the Commons

\section{INTRODUCTION}

Complex social-ecological systems (SES) often exhibit system dynamics characterized by emergence, where system properties, like state or output variables, cannot be fully explained by input variables (Trosper 2005). Systems encompassing common pool resources are particularly complex because the SES involves multiple users and nested governance structures. Following the work of Ostrom (1990), a multitude of case studies have been conducted to analyze problems, patterns, and determinants of sustainable use in common pool resource systems. Whereas the SES framework (Ostrom 2009) already provides guidance on analyzing all components of a system in a structured way in order to make case-specific data comparable, approaches for metaanalyses and building explanatory models lag behind. Emergence and complexity cause particular challenges for unravelling resource use problems and their causes because problem dynamics might differ from case to case despite similar input variables. Thus, a stronger focus on the system itself and its dynamics is necessary while input variables might be relegated to important factors.

The archetype approach with a focus on system dynamics might thus provide a means to tackle emergence and complexity in the analysis of resource use problems in SES. The archetype approach aims to identify "building blocks of society-nature interaction that reappear in multiple case studies" (Eisenack, Lüdeke, and Kropp 2006:1, unpublished manuscript, https://www.unioldenburg.de/fileadmin/user_upload/wire/fachgebiete/envdev/download/ arch-eisenack3.pdf). In keeping with this understanding, archetypes can explain the outcomes of particular factor combinations. Several archetypes might occur simultaneously in one case or represent rival outcomes of slightly different factor combinations. Therefore, the archetype approach can bridge the gap between case-specific constellations and grand theory by allowing a medium level of abstraction and multiple constellations of attributes and outcomes (Eisenack et al. 2019). Thus, the complexity of problems can be taken into account without the need to find a "one size fits all" explanation. Approaches to identify archetypes have been conducted for different units of analysis and using qualitative or quantitative methods (Václavik et al. 2013, Oberlack et al. 2016, Hartel et al. 2018, Oberlack and Eisenack 2018, Vidal Merino et al. 2018; see also Oberlack et al. 2019 for further references).

We use the archetype approach with a focus on system archetypes that aim at recognizing recurrent structures and internal dynamics of a system (Senge 2006). Instead of describing linear causal relationships, system researchers focus on feedback loops producing and explaining particular characteristics of the system. Thus, the approach is especially suited to tackling characteristics of emergence. System archetypes are defined as basic, recurrent patterns of feedback loops in the system that can produce similar dynamics in different contexts (Wolstenholme 2004, Senge 2006). Until now, up to 10 system archetypes are described in the literature (Kim and Anderson 1998), among them, e.g., Tragedy of the Commons, Drifting Goals, or Fixes that Fail. These have already been applied to explain different environment and resource-related problems in social-ecological systems (e.g., Prusty et al. 2014, Brzezina et al. 2017), and also to land use changes (Banson et al. 2016, Turner et al. 2016, Tenza et al. 2017). These authors mainly analyzed single case studies, while multiple and comparative case studies using system archetypes have not been, to the best of our knowledge, yet conducted. Thus, none of

${ }^{1}$ Faculty of Law and Economics \& Institute of Botany and Landscape Ecology, University of Greifswald, Germany, ${ }^{2}$ Department of Farm Management, Faculty of Organic Agricultural Sciences, University of Kassel, Germany, ${ }^{3}$ Department of Economics and Finance Theory, Azerbaijan State Agrarian University, Ganja, Azerbaijan 
these studies has used system archetypes to conduct archetype analysis, i.e., to explain multiple and potentially rivalrous factor and outcome constellations.

The archetype analysis using system archetypes is employed to disentangle problem dynamics of complex SES using the example of common pasture management in the postsocialist Caucasus region. As in several countries of Central Asia, different pasture management problems ranging from severe degradation to underuse are prevalent there (Behnke 2008, Li et al. 2012, Neudert et al. 2015, Raaflaub and Dobry 2015). In the Caucasus region, after severe declines in the 1990s, livestock numbers have been increasing since 2000 , leading to an overall scarcity of pasture resources. In combination with unsustainable pasture management practices and climate change problems, pasture degradation and erosion increased (Neudert et al. 2015, Raaflaub and Dobry 2015, Shatberashvili et al. 2015). Pasture systems have already undergone far-reaching shifts in management in the postsocialist period and a range of policy options allegedly enabling sustainable management are still under discussion (Bassett 2009, Kerven et al. 2012, 2016, Notenbaert et al. 2012, Yu and Farrell 2013, Basupi et al. 2017). However, common management as a one size fits all solution does not seem feasible (Neudert 2015a, Moritz et al. 2018).

In an interdisciplinary analysis of comparative case studies, we apply the existing system archetypes, e.g., Tragedy of the Commons or Fixes that Fail to the context of common village pasture management to unravel the internal dynamics and feedbacks of different pasture management problem aspects. Drawing on the archetype definition of building blocks, we also explore how different problem aspects are linked and contribute to the overall dynamics in the system. Using this system understanding of pasture management problems, we identify possible interventions for breaking negative feedback loops. No study so far has applied archetype analysis or system archetypes to pasture use or pasture management problems. Thus, in this paper we go beyond existing studies by applying system archetypes to the social-ecological system of common pasture use to characterize recurring problems of pasture management.

To achieve an interdisciplinary understanding of common village pasture management and to systematically address contextual factors and outcomes, we frame common village pastures as complex social-ecological systems and use the variables of the SES framework (Ostrom 2009). Employing the SES variables also makes it possible to address contextual factors and outcomes in a systematic way and thus facilitates the exploration of linkages between context, problem dynamics, and outcomes. One factor well known for influencing governance of pasture resources is scarcity (Bromley 1991). In addition, economic and cultural factors might play a role (Neudert 2015a; Salzer, Neudert, and Beckmann, unpublished manuscript). By comparing case studies in two Caucasian countries, Azerbaijan and Georgia, selected along a gradient of resource scarcity, we explicitly consider these factors as potentially influential for the occurrence and severity of management problems.

\section{ANALYTICAL APPROACH AND METHODOLOGY}

Application of the archetype approach and system archetypes A systems model focuses on causal and feedback relations and explains the system's behavior over time (Senge 2006). The basic components of systems are feedback loops, producing either reinforcing or balancing dynamics (Fig. 1). Reinforcing feedback loops consist either of only positive causal relationships or an equal number of negative causal relationships and produce accelerating system dynamics. In contrast, balancing feedback loops involve an unequal number of negative causal relations that cause the system to persist in a certain state. The dynamics might also be influenced by delays, describing a time lag or only partial connection in a causal relationship. Although quantitative modeling is also possible, the conceptualization of system dynamics and the design of a qualitative model is crucial for understanding the system (Luna-Reyes and Andersen 2003).

Fig. 1. Basic structures of system archetypes: positive (+) and negative (-) connections. Only positive connections or an equal number of negative connections produces a reinforcing feedback loop (R1) while an unequal number of negative connections results in a balancing feedback loop (B2). The delay mark (II) indicates a time lag or partiality in connections

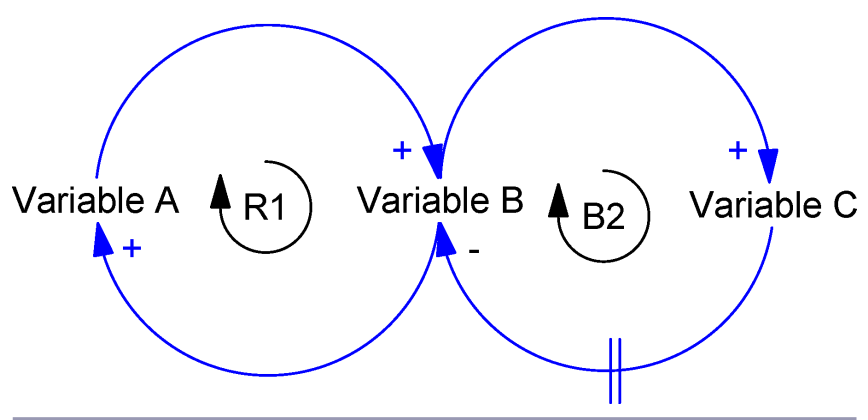

System archetypes, defined as "certain patterns of structure [that] reappear again and again" (Senge 2006:93), consist of a combination of balancing and/or reinforcing feedback loops and, because of their generic structure, can be applied to a variety of contexts. They are particularly useful in explaining counterintuitive results and unintended consequences of wellintentioned actions (Wolstenholme 2004). Because system archetypes focus on reappearing problem structures, several archetypes may occur in one case at the same time. Until now, up to 10 system archetypes are described in the literature (Kim and Anderson 1998), among them, e.g., Tragedy of the Commons, Drifting Goals, or Fixes that Fail.

System archetypes are a useful approach for identifying "building blocks of society-nature interaction that reappear in multiple case studies" (Eisenack, Lüdeke, and Kropp 2006:1, unpublished manuscript). The archetype approach in the sense of Oberlack et al. (2019) is defined as an approach aiming to functionally classify outcomes of social-ecological systems. Thus, a middle range of abstraction can be achieved, filling the gap between overarching theories and case study data. Hence, in principle, the approach is compatible with any framework, theory, or method. System archetypes are one approach to archetype analysis that has been used already for pattern identification, diagnosis, and scenario development (Oberlack et al. 2019).

Sietz et al. (2019) review different methodological approaches to archetype analysis ranging from qualitative to quantitative approaches. Among the qualitative methods for archetype analysis, our approach can be classified as an expert/stakeholder 
assessment, which is particularly applicable to identify causal mechanisms and to derive normative statements, in our case about the sustainability of pasture management (Sietz et al., 2019). It is particularly suitable to incorporate complex, interdisciplinary case study data like ours. For the archetype analysis, we draw on six case study villages, while several pasture management problem archetypes can reappear in each case.

No straightforward method is described for the identification and application of system archetypes, but rather iterative and multistep processes are recommended (Luna-Reyes and Andersen 2003, Gharajedaghi 2011). In our case we applied system archetypes in an inter- and transdisciplinary multilevel analysis of six cases from two different countries in one geographical region.

Starting with individual, disciplinary data and analysis as input, the team of researchers engaged in an interdisciplinary analysis for identifying cause-and-effect relationships centering around pasture condition and management, contrasting the different case study villages. To facilitate interdisciplinary communication and the comparative analysis, during this first step we applied the social-ecological systems (SES) framework to common village pasture use in the Caucasus region (Ostrom 2009, McGinnis and Ostrom 2014). The framework has been widely used for analyzing resource use problems in an interdisciplinary way and is particularly helpful in creating a common language between researchers from multiple disciplines (Cox 2014, Mee et al. 2015, Williams and Tai 2016). We adapted the second-level variables as defined by Ostrom (2009), as presented in Table A1.1. This step also involved a cross-check and triangulation of data from the different collection methods. In the results, we refer to the SES variables by short indicators in brackets, e.g., ECO1 or U2.

In a second step, results on system components for each case study village were discussed in half-day participatory presentation and discussion sessions with the villagers to obtain feedback on identified cause-and-effect relationships (Luna-Reyes and Andersen 2003). Moreover, we engaged in discussions on how to improve pasture condition. Input from these discussions was subsequently reflected upon within the research team and included in the interdisciplinary analysis.

In a third step, the research team worked in several sessions iteratively toward the identification and verification of important cause-and-effect relationships by rearranging, synthesizing, and reducing complex data. Thus, a simultaneous understanding of the system structure, processes, and modifying factors could be achieved (Gharajedaghi 2011). Emerging elements and relationships were tested against evidence from the researchers' own disciplinary data and background knowledge, as well as villagers' statements from discussion sessions in the field. This partly involved a further analysis of disciplinary data with regard to specific interdisciplinary questions arising in the process. Although the first steps were done by creating mind maps and causal loop diagrams with moderation material on paper, later steps were conducted using Vensim modeling software (Vensim PLE software, Version 7.2a).

After achieving an interdisciplinary understanding of the complex system as a whole, specific recurring patterns and problem constellations became apparent. Descriptions of system archetypes were now discussed and used as lenses for identifying and unravelling the dynamics leading to the recurring problem constellations (Kim and Lannon 1997, Kim 2000a, b). Dynamics were further tested and discussed within the research team to reflect the essentials of systemic behavior in the case studies (Kim and Lannon 1997). We finally selected three system archetypes for application (Tragedy of the Commons, Shifting the Burden, and Success to the Successful). Within the research team we saw potential to apply other system archetypes, e.g., Fixes that Fail, which could be applied in a slightly different way from the Shifting the Burden archetype. Other archetypes, e.g., Growth and Underinvestment could not be reasonably applied to pasture management problem dynamics in our case studies. Thus, the three selected archetype applications represent the most prevalent problem dimensions in village pasture management that recur in multiple case studies. Moreover, the selected archetypes provide coherent insights into problem dynamics consistent with data available for each case.

Finally, in a last step, based on the preceding discussions with villagers, the research team discussed how to design interventions to address the underlying systemic dynamics leading to problems (Kim and Lannon 1997, Stroh 2015). In system dynamics logic, this is made possible by breaking or adding links, or shortening delays (Kim and Lannon 1997). All measures should aim at designing high-leverage interventions, which have high potential to change system dynamics by targeting crucial system mechanisms (Stroh 2015). All interventions designed for the applied archetypes aim at developing self-governance as one potential way to approach sustainable resource management (Ostrom et al. 1999). Self-governance is interpreted in a wide sense, which may include supporting interventions by the government or the design and consolidation of nested governance structures across scales. As alternative approaches the researcher team discussed the design and enforcement of externally designed rules and the privatization of common pastures (Acheson 2006). Potential pitfalls and opportunities of these policy options have been discussed in detail in many contexts, including natural resource management (Cox 2016), yet matching policy options to the context seems to be most important (Acheson 2006). Considering government control we argue that because of the fragility of state governance in the Caucasus region and the failure of centralistic resource management approaches in the past, this option does not have high potential for sustainably governing natural resource use in the region. The privatization of common pastures is realistically discussed as a policy option by the Georgian government but heavily opposed by villagers. Mounting evidence shows that privatizing common pastures avoids some problems, but leads to others (Neudert 2015a).

Thus, after a careful consideration of policy options and in accordance with the opinion of local stakeholders, we concentrated on designing options aimed at strengthening selfgovernance. Possible actions or attempts to design measures for resolving problems are described following the archetype characterizations. Finally, we abstracted a self-governance solution archetype.

\section{Case study selection}

We focus on Azerbaijan and Georgia as two adjacent South Caucasian countries with a postsocialist transition background. Our study regions are the neighboring regions Kakheti in Georgia and Ganja-Gazakh in Azerbaijan (Fig. 2) because both have 
similar climatic conditions and livestock keeping is of high importance within the countries.

Fig. 2. Location of case study villages (in bold) in Azerbaijan and Georgia. Sources: https://gadm.org/; http:// naturalearthdata.com/; http://srtm.csi.cgiar.org/.

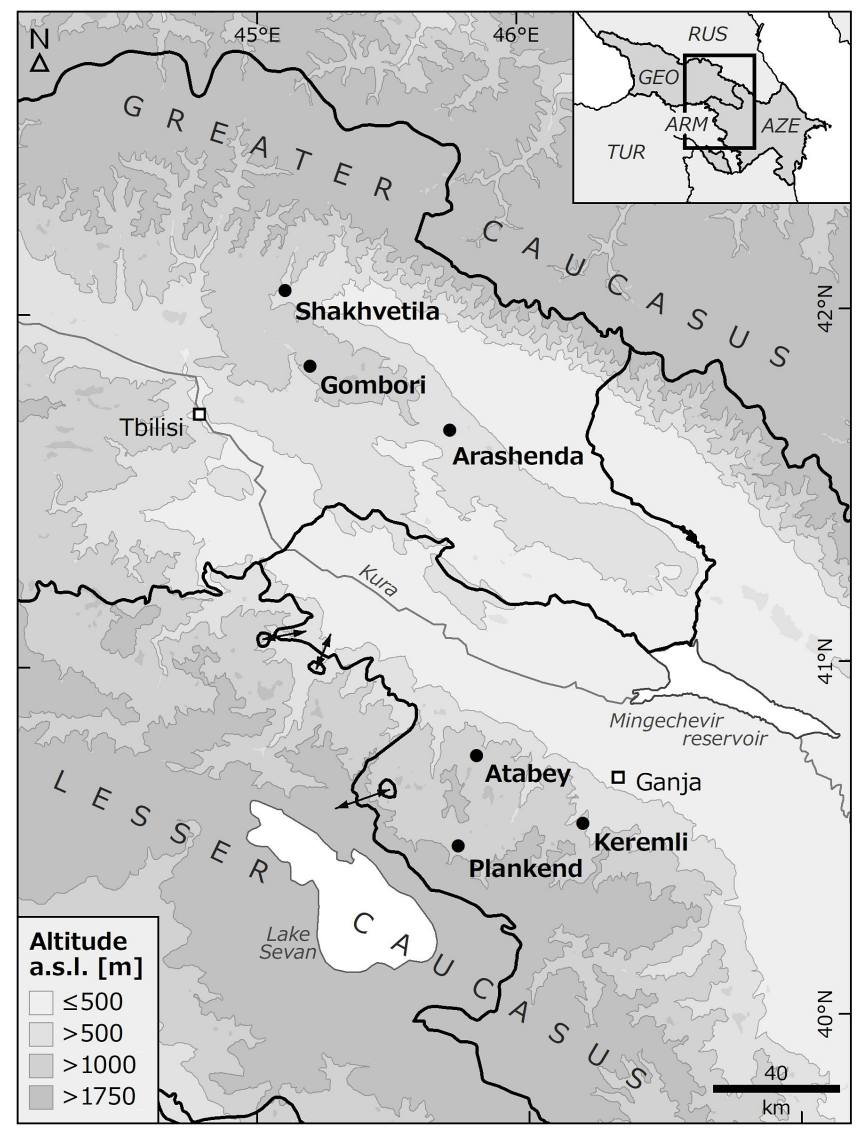

The study is based on a comparative case study approach because this allows the use of qualitative and quantitative data from different disciplines, with results being achieved by triangulating and combining data (Yin 2003). Our unit of analysis is the village because a delimitation of pasture resources and corresponding user groups is feasible at this level. We selected three case study villages located in different districts in each country. Therefore, our case study exceeds the minimum requirement of four cases for identifying valid recurring patterns for the archetype approach (Eisenack et al. 2019). Additionally, the cases allow an analysis of differences between Georgia and Azerbaijan as well as different levels of resource scarcity. Our selection criteria for study villages were the following: (1) Location in an altitudinal belt between 650 and $1600 \mathrm{~m}$ a.s.1., which delimits the zone where common pasture use has a substantial share in land use. (2) Villages vary according to the village pasture area per household depicting pasture scarcity and arable land area per household indicating potential alternatives to pasture use in arable farming. The indicators were calculated based on statistical information. (3) Villages differ in remoteness and in infrastructural conditions, as indicated by the distance from district centers and the presence of an asphalt road to the villages. (4) As a last step we considered whether the village population and administrations were open to the presence of researchers (Allahverdiyeva, Bregvadze, Didebulidze, et al. 2015, unpublished manuscript, https://www.researchgate.net/

publication/329269094_Baseline_Study_of_Co4_project_final_report). Figure 2 and Table 1 present the finally selected villages and the selection criteria.

\section{Data basis}

Data was gathered and analyzed by an interdisciplinary and multinational team of researchers with diverse methods in several fieldwork periods over two years. Researchers brought in expertise from diverse fields ranging from ecology and animal husbandry to economics, institutional economics, and ethnology. All data collection took place in the case study villages (Table 1).

\section{Rapid rural appraisal study}

In 2015 the team conducted an exploratory study investigating pasture use, management, and condition (Allahverdiyeva, Bregvadze, Didebulidze, et al. 2015, unpublished manuscript) borrowing methods and tools from the rapid rural appraisal approach (Freudenberger 2008), farm economic methods (Kay et al. 2012), and applied pasture monitoring methods (Etzold and Neudert 2013). The team spent one to four days in each of the case study villages. For researchers not proficient in the local languages, interviews were consecutively translated into English.

\section{Socioeconomic information}

In order to understand the incentives and motivations for livestock keeping in individual farm households of the case study villages, data on assets, income sources, and livestock keeping practices was gathered with a structured questionnaire (Benedetti et al. 2010, Nuthall 2011). In total, 392 face-to-face interviews were obtained from livestock keeping households (see Table 2). Because of the absence of reliable information on the household population, a convenience sample with a high sampling rate was chosen (Bailey 1978). Data were analyzed using quantitative approaches with Microsoft Excel and SPSS (Schwetz et al. 2013).

\section{Economic field experiments}

We used a framed field experiment approach (Cardenas et al. $2000)$ to assess the capacity of village households to solve common-pool resource management problems in a game setting. The experiments are based on a protocol of rangeland and fishery experiments (Cardenas et al. 2008, Prediger et al. 2011). In each session, each of five players could decide to "graze" one of the two game pastures with a grazing intensity level (no grazing, low and high intensity). Grazing one pasture with more than a previously set maximum total stocking rate resulted in the degradation of the game pasture, while the formerly good state could be reestablished by resting the pasture for two rounds. Thus, the design takes into account the resource limit, intertemporal grazing dynamics, and nonlinear payoffs, which also characterize grazing on village pastures. The experimental design was adapted to the local situation and extended by a questionnaire and participant observation.

Each field experimental session consisted of two parts with different treatments, which was not communicated to the players in advance. The first 10 rounds were conducted without communication; for the other 10 rounds players were allowed to communicate and agree on a strategy, and, if desired, further communicate throughout the following rounds. In total, the 
Table 1. Selected case study villages.

\begin{tabular}{|c|c|c|c|c|c|c|}
\hline \multirow[b]{2}{*}{ District name } & \multicolumn{3}{|c|}{ Azerbaijani case study villages } & \multicolumn{3}{|c|}{ Georgian case study villages } \\
\hline & Shemkir & Göy-göl & Gedebey & Akhmeta & Sagarejo & Telavi \\
\hline Village name & Atabey & Keremli & Plankend & Shakhvetila & Gombori & Arashenda \\
\hline Altitude (m a.s.1.) & 1300 & 996 & 1450 & 680 & 1150 & 760 \\
\hline Total number of households & 186 & 97 & 276 & 89 & $655^{\dagger}$ & $720^{\dagger}$ \\
\hline Distance to district center $(\mathrm{km})$ & 37 & 10 & 10 & 12 & 53 & 10 \\
\hline Presence of asphalt road & no & yes & yes & no & yes & yes \\
\hline Total arable land area (ha) & 346 & 182 & 450 & $120^{\dagger}$ & $681^{\dagger}$ & $2752^{\dagger}$ \\
\hline Arable land area (ha/household) & 1.86 & 1.87 & 1.63 & 1.34 & 1.04 & 3.83 \\
\hline Total pasture area (ha) & 863 & 517 & 94 & $411^{\dagger}$ & $1846^{\dagger}$ & $350^{\dagger}$ \\
\hline Pasture area (ha/household) & 4.64 & 5.33 & 0.34 & 4.62 & 2.82 & 0.49 \\
\hline
\end{tabular}

sample size amounted to 43 experiments; hence, in total 215 players participated (Table 2).

\section{Pasture governance}

Pasture governance is investigated drawing on institutional economics approaches and qualitative research methods (Atteslander 2000). After identifying stakeholders in pasture use and administration in a stakeholder analysis (Aaltonen 2011), the institutions, i.e., the rules and regulations of pasture use (North 1990) were investigated in more detail. Laws and regulations concerning pasture governance were assessed in a review of laws and decrees and through semistructured interviews with relevant local and regional administrations. Information on actual practices of pasture use and implementation of formal rules was gathered in qualitative interviews with villagers selected to represent the relevant stakeholder groups. Data was analyzed using a qualitative approach with the software Atlas.ti using a mixture of descriptive and process coding (Miles and Huberman 1994). In total, 150 interviews were conducted in all case study villages with different stakeholder groups (Table 2).

\section{Ecological data}

To collect data on properties relevant for pasture productivity and condition, we adapted the methodology of Etzold and Neudert (2013) developed as a comprehensive tool for assessing pasture condition and management in the Caucasus. For all six village pasture territories a random selection sampling design was developed by means of a Geographic Information System (GIS; Etzold et al. in preparation). Exact village pasture borders were only known in the Azerbaijani case study villages, while for the Georgian ones approximate borders were drawn.

Field measurements and estimations on the selected plots took place on a $10 \times 10-\mathrm{m}$ area. Information collected encompassed on the one hand physical site parameters not alterable by human or livestock-related impact (first column in Table 3), which are used for assessing potential erosion on the particular site in a Susceptibility to Erosion-Index (SEI). On the other hand, parameters that can be affected by humans and livestock were collected representing erosion phenomena and the state of the vegetation in a Pasture Degradation Index (PDI; second column of Table 3). Additionally, coarse information on vegetation composition, e.g., share of woody plants, was collected. In total,
220 plots were assessed on the Azerbaijani and 206 on the Georgian village pasture territories (Table 2).

All data was entered into MS Excel and processed with the statistical platform R 3.0.2 (R Foundation for Statistical Computing, Vienna, Austria). From four variables (inclination, aspect, slope position, and configuration) the Topographic Relative Moisture Index (TRMI 0-60, $0=$ low, $60=$ high moisture availability; Parker 1982) was derived. Furthermore, the two indices (Table 3 ) were calculated following a scheme explained in detail in Etzold and Neudert (2013) where weighted scores get assigned to each measured or estimated value. In contrast to the original source both indices were altered to suit the local situation (Etzold, Merabishvili, and Quliev, unpublished manuscript).

No direct measurements of pasture productivity were conducted, e.g., phytomass harvests, ideally from exclosure experiments. However, assessed information indirectly suggests differences in the productivity of the six village pastures. Because none of the respective villages hosts a climate station, information was retrieved from freely available projected climate data (https://en. climate-data.org).

\section{RESULTS}

\section{The village pasture social-ecological system}

Land use governance in Azerbaijan and Georgia is strongly affected by the postsocialist socio-political restructuring process of the past 25 years (S1). Former socialist collective and state farms' land and agricultural machinery was distributed to households following land reforms (Lerman and Sedik 2010, Mushkelishvili et al. 2012) and new governance forms had to be designed and implemented. Despite the fact that agriculture is still an important source of income in rural areas, it still relies mainly on comparatively small farm-household structures and suffers from productivity and efficiency problems (Lerman 2006).

Livestock numbers in both countries decreased markedly in the immediate transition period (Didebulidze and Plachter 2002), but later began increasing (S2). Especially in Azerbaijan, sheep numbers are heavily increasing because of high availability of capital, high prices for sheep meat, and cultural preferences for locally slaughtered sheep (Neudert 2015b). In Georgia, increasing livestock numbers have been observed since approximately 2008 (National Statistics Office of Georgia 2017). Thus, both countries 
Table 2. Data collection in the case study villages and on village pasture.

\begin{tabular}{|c|c|c|c|c|c|c|c|}
\hline \multirow[t]{2}{*}{ Unit } & \multicolumn{3}{|c|}{ Azerbaijani case study villages } & \multicolumn{3}{|c|}{ Georgian case study villages } & \multirow[b]{2}{*}{ Arashenda } \\
\hline & & Atabey & Keremli & Plankend & Shakhvetila & Gombori & \\
\hline Permanently living households in village & Household & $117^{\dagger}$ & $80^{\dagger}$ & $221^{\dagger}$ & 85 & 285 & $355^{\dagger}$ \\
\hline Household engaged in livestock keeping & Household & 97 & 69 & 168 & 83 & 150 & 78 \\
\hline \multicolumn{8}{|l|}{ Socioeconomic information } \\
\hline Sampled households for structured interviews & Household & 83 & 43 & 72 & 37 & 82 & 75 \\
\hline Sampling rate (structured interviews) & $\%$ of households & 86 & 62 & 43 & 45 & 55 & 96 \\
\hline \multicolumn{8}{|l|}{ Economic field experiments } \\
\hline Number of experiments & Experiment & 8 & 8 & 8 & 3 & 8 & 8 \\
\hline Number of participants & $\begin{array}{l}\text { Number of } \\
\text { participants in } \\
\text { experiments }\end{array}$ & 40 & 40 & 40 & 15 & 40 & 40 \\
\hline \multicolumn{8}{|l|}{ Pasture governance } \\
\hline $\begin{array}{l}\text { Semistructured interviews with } \\
\text { administrations }\end{array}$ & Interview & 9 & 6 & 7 & 4 & 4 & 7 \\
\hline $\begin{array}{l}\text { Interviews with the village population and } \\
\text { other local stakeholders }\end{array}$ & Interview & 16 & 14 & 16 & 8 & 35 & 24 \\
\hline \multicolumn{8}{|l|}{ Ecological data } \\
\hline Total number of plots assessed & Vegetation plot & 129 & 77 & 14 & 53 & 98 & 55 \\
\hline Plots/pasture area & $\begin{array}{l}\text { Number of vegetation } \\
\text { plots/100 ha }\end{array}$ & 14.9 & 14.9 & 14.9 & 44.2 & 19.6 & 15.7 \\
\hline
\end{tabular}

Table 3. Main parameters assessed on $10 \times 10-\mathrm{m}$ plots and their assignment to two indices after Etzold and Neudert (2013)

\begin{tabular}{ll}
\hline \hline $\begin{array}{l}\text { Susceptibility to Erosion-Index } \\
\text { (SEI) }\end{array}$ & Pasture Degradation-Index (PDI) \\
\hline Altitude & Cover of bare soil \\
Inclination & Cover of rubble and rocks \\
Aspect & Cover of livestock tracks \\
Topographic position & Cover of erosion tracks \\
Slope configuration & Browsing tracks (percentage of \\
& plants browsed) \\
Hardness of bedrock & Cover of grazing indicator species \\
& $\begin{array}{l}\text { Flowering plants (few, medium, a } \\
\text { lot) }\end{array}$ \\
& Number of plant species on $3 \times 3$ \\
& m 3 \\
\hline
\end{tabular}

have a similar transition background, but show partly differing developments in the postsocialist transition period.

Common village pastures are spatially defined according to administrative maps and the presence of a common use system. The size of different village pasture areas is shown in Table 1 (RS3). All case study villages are located in the temperate humid forest zone, providing predictable, though markedly seasonal fodder production (RS5, RS6, RS7). Snow cover makes grazing impossible during the winter months, and the grazing season is longer in villages located at lower altitudes. The grazing season, as stated by villagers, ranges from 190 to 250 days.

For assessing the productivity and potential stocking rate (RS5, RU2, RU5), we used several indicators because no direct measurements are available (Table 4). Because annual precipitation in the three Georgian villages is considerably higher, plants are better provided with water, and therefore also their regeneration ability after disturbances is higher. Consequently, this most likely results in higher productivity and hence higher fodder availability (RS5). Actual water availability to vegetation and hence regeneration ability is also driven by the topography of a site as expressed by the Topographic Relative Moisture Index (TRMI). Differences between different villages are mostly not significant, although variation between different sites, e.g., southern and northern slopes, is considerable (RU7). An indirect measure of productivity is mean vegetation height. Although it is interlinked with grazing pressure (stocking rate) it is remarkably higher in Georgia, which might be partly due to the abovementioned precipitation levels.

For potential stocking rates and the stocking capacity, only approximate values are available (RU5). Governmental regulations in Azerbaijan prescribe a stocking rate of 1-8 sheep per hectare for village pastures depending on plot quality (Ministers' Cabinet of Azerbaijani Republic 2000, Aliyev 2007). The Georgian legislation, e.g., the Law on Soil Protection, requires proper use according to the "established allowed maximum headcount," but exact maximum stocking rates are not defined ("Law of Georgia on Soil Protection," issued 12.05.1994, amended 19 November 2002, No. N 1751). However, because of the higher precipitation and higher mean temperatures in the Georgian villages, slightly higher maximum stocking rates can be expected for Georgia.

Common village pastures are currently administered by the state in both countries (GS1), although governance approaches differ substantially. In Azerbaijan, common village pasture land is administratively placed under the responsibility of the local self- 
Table 4. Indicators for pasture productivity based on online resources and plot information.

\begin{tabular}{|c|c|c|c|c|c|c|c|}
\hline \multirow[t]{2}{*}{ Item } & \multirow[t]{2}{*}{ Unit } & \multicolumn{3}{|c|}{ Azerbaijani case study villages } & \multicolumn{3}{|c|}{ Georgian case study villages } \\
\hline & & Atabey & Keremli & Plankend & Shakhvetila & Gombori & Arashenda \\
\hline Altitude of plots & m a.s.l. & $1481(151)$ & $1098(95)$ & $1518(37)$ & $738(93)$ & $1298(187)$ & $657(53)$ \\
\hline $\begin{array}{l}\text { Precipitation/ } \\
\text { temperature }\end{array}$ & $\begin{array}{c}\text { annual mean } \\
\mathrm{mm} /{ }^{\circ} \mathrm{C}\end{array}$ & $589 / 8.6^{\dagger}$ & $514 / 10.8^{*}$ & $571 / 8.3^{\S}$ & $764 / 11.1^{\mid}$ & $798 / 9.5^{-1}$ & $704 / 11^{\#}$ \\
\hline SEI & Index & $67(10)$ & $62(13)$ & $74(9)$ & $59(11)$ & $52(12)$ & $68(9)$ \\
\hline TRMI & Index & $29(5.7)$ & $29(8.6)$ & $31(8)$ & $31(7)$ & $25(7)$ & $33(6)$ \\
\hline Vegetation height & $\mathrm{cm}$ & $8(4)$ & $7(6)$ & $3(1)$ & $9(8)$ & $11(7)$ & $16(6)$ \\
\hline
\end{tabular}

administration authority (Belediyye; "Law on Status of Local Self-Administration," No. 698-IQ, issued 2 July 1999). Actual management responsibilities are placed in the hands of the village population without further provisions. In practice, village assemblies may serve as the relevant decision-making units (GS6) while a mediating and facilitating role is assigned to the local selfadministration authority (GS7).

In Georgia, the governance of land and pasture resources is still being reorganized. Since 2008, common village pasture land is administered by the Ministry of Economy and Sustainable Development (GS1) because privatization of pasture resources is planned (Mushkelishvili et al. 2012). The local administrative bodies have no legal responsibilities regarding pasture resources and there are no legal provisions for management in place (GS6, GS7). It is still unclear how common use can be dealt with in a possible privatization process (Neudert, Theesfeld, Didebulidze, et al., unpublished manuscript). Therefore, the formal property rights assignment for common pastures in Azerbaijan can be described as a comanagement between the local selfadministration authority and the village population, whereas for Georgia the situation is currently an open access regime without management authorities and rules (GS4; Neudert, Theesfeld, Didebulidze, et al., unpublished manuscript).

The main users of common village pastures are households resident in the case study village, who are smallholders characterized by diversification of income sources (Ellis 1988). Their livelihood relies on semisubsistence agriculture as well as different off-farm income sources, e.g., pensions or salaried work. Data on the self-assessed importance of income sources shows that livestock keeping is often considered as the first or second most important income source (U8; Allahverdiyeva 2018, unpublished manuscript, https://www.researchgate.net/

publication/333877932 Socio-economic analysis of farming households in the case study villages of Azerbaijan_and_Georgia by Naiba Allahverdiyeva Final Report). The relationship between livestock keeping and other income sources is complex: livestock has cultural and social importance, but also the important function as capital investment. The availability of savings and capital might thus increase investment in livestock, but on the other hand, household labor shortages and off-farm occupations might restrict the possibility to keep livestock (Allahverdiyeva 2018, unpublished manuscript). A stable off-farm income source significantly improves the income situation of households. However, off-farm occupation possibilities are strongly restricted in remote villages with bad infrastructural access, particularly in Atabey and Shakhvetila (Table 1). Data on livestock possessions and other socioeconomic indicators for the case study village households is presented in Table A2.1.

Besides village pastures, summer pastures in the Greater and Lesser Caucasus (June-September, mostly above $1700 \mathrm{~m}$ a.s.1.) and winter pastures in the lowland semideserts (October-May, mostly below $500 \mathrm{~m}$ a.s.1.) are valuable grazing resources (ECO1). Thus, vertical livestock migration systems interact strongly with the described sedentary forms of livestock keeping on common village pastures. In the Ganja-Gazakh region mobile livestock keeping systems connect the winter pastures in Jeiranchel region with summer pastures in the Lesser Caucasus with migration distances of approximately $70-100 \mathrm{~km}$. In Kakheti region, a mobile livestock keeping system with more than $200 \mathrm{~km}$ of migration distances connects the winter pastures in the region of Dedoplistskaro with summer pastures in Tusheti, Mtianeti, and Javakheti regions (Salzer 2016).

Thus, besides households residing permanently in the case study villages (sedentary livestock keepers), common village pastures are used by semimobile or mobile pastoralists from the village itself and from elsewhere (ECO3). Some of the village households keep livestock in a semimobile or mobile way using summer and/ or winter pastures themselves. Mobile livestock keepers may pass by the village only during migration and may use the village pasture some days up to several weeks (temporary use). Semimobile livestock keepers use other pastures during winter or summer. If winter pastures are used, semimobile livestock might graze on the village pasture for nearly as much time as sedentary livestock. Mobile and semimobile pastoralists can exert significant grazing pressure on common village pastures and thus are an important stakeholder group.

\section{Recurring problems of village pasture management and possible solutions}

We apply three system archetypes, Tragedy of the Commons, Shifting the Burden, and Success to the Successful, to explain the dynamics of different problem constellations occurring repeatedly in the pasture management in the case study villages. Directly relevant SES variables are marked in Table A1.1 in Appendix 1. 
Too much livestock on the pasture (Tragedy of the Commons archetype)

The Tragedy of the Commons archetype underlines that individual decisions for individual gain might add up to negative collective outcomes in an open access resource use system. The archetype was first described by Hardin (1968) using the example of pasture resources, but the problem dynamics can be generalized to open access resources of any type with high use pressure.

The archetype consists of four reinforcing and two balancing feedback loops, applying equivalently to two pasture users A and $\mathrm{B}$ : The positive net gains incentivize each participant to use the pasture more intensively as long as the overall use rate is within the village pasture limit (R1 and R2 in Fig. 3). Thus, the higher A's village pasture stocking, the higher the net gain for A from using the common village pasture. A higher net gain will again incentivize A to increase his village pasture stocking. Additional users might become interested in the pasture as well. However, if the resource is used beyond its limits and gains decrease, users often respond with intensifying resource use (R3 and R4), thus accelerating overuse and the depletion of the resource (Kim $2000 \mathrm{~b}$ ). On the contrary, reduced gains per individual activity also reduce the individual net gains, which might lead to a reduced individual resource use, thus creating balancing feedback loops (B5 and B6). Depending on the relative strengths of the feedbacks, the resource might be partly or completely depleted.

Fig. 3. The Tragedy of the Commons archetype leading potentially to unsustainable common village pasture management (red) and solution by communication and rule development (blue).

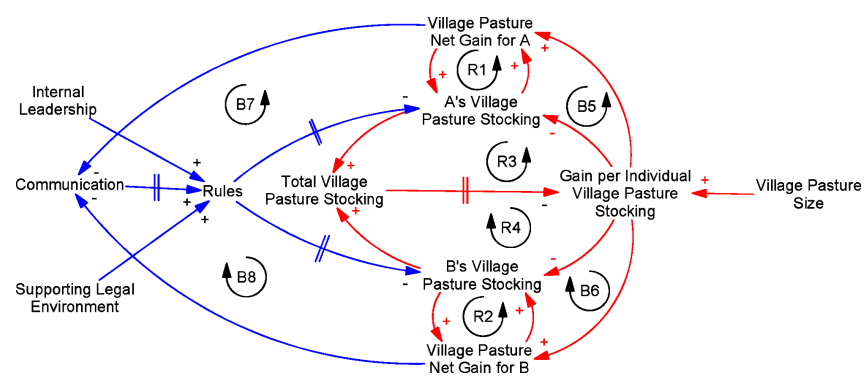

For investigating whether the Tragedy of the Commons archetype is present in the case study villages, we look at the stocking rate on village pastures, pasture quality, and perceptions of pasture quality based on case study material. An indicator of the state of the system is the stocking rate, which is calculated by dividing the total village pasture stocking by the village pasture size. Because users consist of many individuals who can be assigned to different stakeholder groups, we calculated actual stocking rates based on actual access, number of households and livestock numbers from survey data (Fig. 4, calculation in Table A2.2; combination of U1, U2 and RS3). In all villages except Atabey, the grazing pressure is higher than the recommended maximum eight sheep units/ha for Azerbaijan (RU5). Because the stocking rates for Gombori and Shakhvetila are only slightly higher than the recommended stocking rate and pasture productivity (RS5, RU5) is expected to be higher for the Georgian villages, the actual stocking rates might be still below stocking capacities for these two villages. Severe overstocking occurs only in Plankend and Arashenda. This is where the size of the village pasture in relation the number of households is very small (Table 1).

Fig. 4. Grazing pressure on pastures in the case study villages by different stakeholder groups.

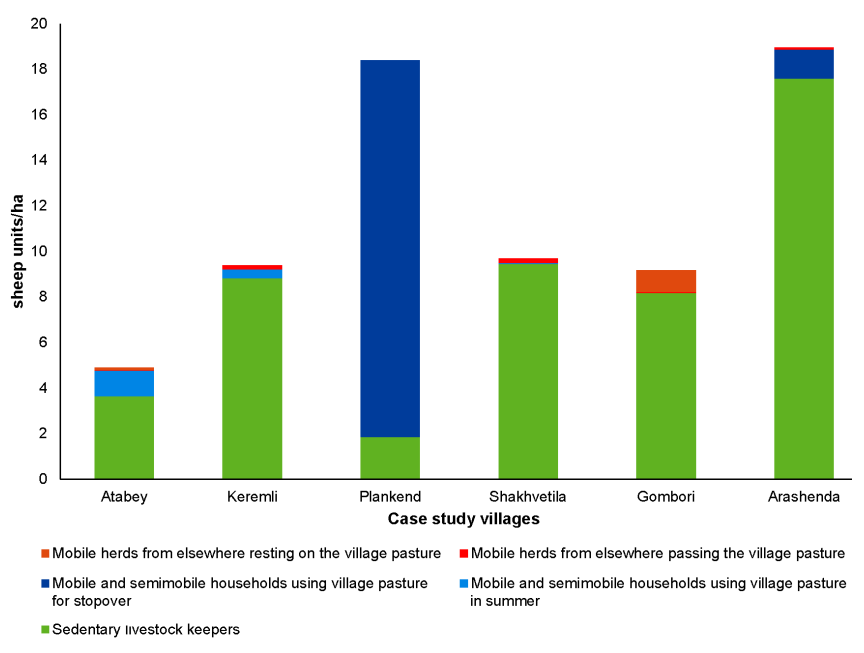

The actual pasture quality was measured by ecological investigations using the Pasture Degradation Index (PDI) reflecting the current pasture condition on plots by uniting parameters representing erosion phenomena and the state of the vegetation $(\mathrm{O} 2)$. As shown in Figure 5, surprisingly according to this index the pastures of Gombori and Shakhvetila display in comparison the worst values despite the hypothesis that more advantageous climatic conditions here allow for better regeneration potential. Also, degradation phenomena would be expected to be less harsh (RU2) and the actual grazing pressure is less than in Arashenda and Plankend. We will come back to this evidence when discussing the Success to the Successful archetype. Apart from the results for these two villages, a slightly decreasing pasture quality with increasing use pressure can be noted for the Azerbaijani case study villages.

Fig. 5. Box-and-whisker plots depicting the range of Pasture Degradation Index (PDI) values. Low PDI value indicates comparatively bad pasture quality.

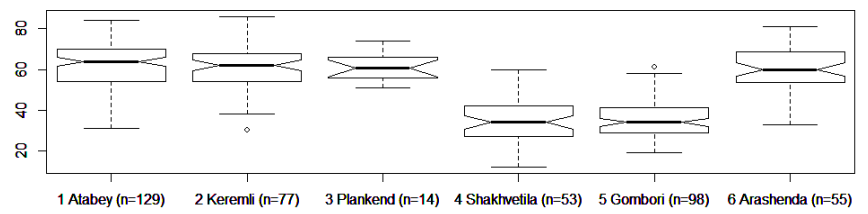

Furthermore, regression tree analyses clearly reveal strong correlations between a smaller distance of a plot to the village (hence the likelihood of livestock frequentation) and a higher PDI or more frequent erosion and browsing tracks. In addition, these analyses point out that patterns of erosion phenomena and the general state of the pasture (PDI) are strongly influenced by topography, i.e., that on southern and steep slopes pasture 
Table 5. Game behavior of villagers in framed field experiments.

\begin{tabular}{|c|c|c|c|c|c|c|c|}
\hline \multirow[t]{2}{*}{ Item } & \multirow[t]{2}{*}{ Unit } & \multicolumn{3}{|c|}{ Azerbaijani case study villages } & \multicolumn{3}{|c|}{ Georgian case study villages } \\
\hline & & Atabey & Keremli & Plankend & Shakhvetila & Gombori & Arashenda \\
\hline $\begin{array}{l}\text { Good pasture quality without } \\
\text { communication }\end{array}$ & $\begin{array}{l}\% \text { of pastures } \\
\text { in rounds }\end{array}$ & 65.6 & 73.8 & 81.3 & 41.7 & 41.9 & 53.1 \\
\hline $\begin{array}{l}\text { Good pasture quality with } \\
\text { communication }\end{array}$ & $\begin{array}{l}\% \text { of pastures } \\
\text { in rounds }\end{array}$ & 87.5 & 76.9 & 96.3 & 93.3 & 88.8 & 81.9 \\
\hline $\begin{array}{l}\text { Difference in pasture quality } \\
\text { (pastures in good quality) }\end{array}$ & $\begin{array}{l}\% \text { of pastures } \\
\text { in rounds }\end{array}$ & 21.9 & 3.1 & 15.0 & 51.6 & 46.9 & 28.8 \\
\hline $\begin{array}{l}\text { Payoff (total per } 5 \text { players) } \\
\text { without communication }\end{array}$ & $\begin{array}{l}\% \text { of optimum } \\
\text { payoff }\end{array}$ & 56.6 & 50.5 & 57.6 & 49.1 & 49.0 & 54.6 \\
\hline $\begin{array}{l}\text { Payoff (total per } 5 \text { players) } \\
\text { with communication }\end{array}$ & $\begin{array}{l}\% \text { of optimum } \\
\text { payoff }\end{array}$ & 67.6 & 54.7 & 66.7 & 74.9 & 70.7 & 69.4 \\
\hline $\begin{array}{l}\text { Payoff difference } \\
\text { (improvement) after } \\
\text { communication }\end{array}$ & $\begin{array}{l}\% \text { of optimum } \\
\text { payoff }\end{array}$ & 11.0 & 4.2 & 9.2 & 25.8 & 21.7 & 14.7 \\
\hline Average age of participants & years & 31.3 & 29.6 & 28 & 42.6 & 29.1 & 36 \\
\hline Gender (female participants) & $\%$ & 13 & 30 & 39 & 47 & 56 & 30 \\
\hline
\end{tabular}

condition is worst (Etzold, Merabishvili, and Quliev, unpublished manuscript).

In addition to the ecological assessment of pasture condition, we asked villagers for their perception of pasture condition and pasture scarcity $(\mathrm{O} 2)$. In Arashenda and Keremli, villagers assessed the pasture quality as good, but they also regard the area available for the village livestock as insufficient, which is confirmed by the grazing pressure calculations (Fig. 4). Only in Atabey, most interviewees rated the pasture quality as good and area as sufficient for the village livestock as confirmed by the comparatively good results in the ecological assessments and the low stocking rate. In Plankend, villagers rate the pasture quality as rather bad because of a high share of visible open soil and low vegetation height while ecological indicators do not show the severity of problems seen by villagers. Moreover, villagers consider the small area as insufficient for the village livestock as indicated by the high stocking rate (Fig. 4). On the contrary, villagers in Gombori and Shakhvetila stated that their pasture areas are reduced by reforestation, subsequently minimizing the fodder basis for their livestock. In Shakhvetila most cattle grazing nowadays even takes place in bushy areas or in forests.

Thus, the evidence shows that the pasture quality perception by villagers partly matches the result of the ecological investigations and the stocking rate calculations. We conclude that the dynamics of the Tragedy of the Commons archetype are most prevalent in the case study villages Plankend and Arashenda, but also in Keremli, while no or only limited evidence of overstocking problems can be found for Atabey, Gombori, and Shakhvetila.

The mechanisms of the Tragedy of the Commons archetype are further confirmed by the fact that in none of the case study villages is resource use by villagers constrained by rules limiting livestock numbers (GS5), despite the growth in livestock numbers in the region in recent years $(\mathrm{S} 1, \mathrm{~S} 2)$ and pasture users' awareness of the limits of their pasture resources (U7). In the interviews with villagers, intensified use was explained with lacking access to alternative grazing resources and the need to earn income, pointing to the individual incentives for overuse (RU5, U8, R1, and R2 in Fig. 3). According to the villagers, overstocking of the pastures already leads to losses in the profitability of livestock keeping as the productivity of livestock decreased or additional supplementary fodder increased costs (O1). This provides evidence of decreasing gains from village pasture use as represented in the archetype with R3 and R4.

Solving the Tragedy of the Commons archetype

Breaking the vicious dynamics leading to the depletion of resources could be achieved by communication resulting from a dissatisfaction about decreasing individual gains from livestock keeping on village pastures and a subsequent agreement on a rule (balancing loops B7 and B8 in Fig. 3). Reduced village pasture net gains might increase communication and rule development, thus decreasing the individual village pasture stocking and the total village pasture stocking below the capacity threshold. A successful completion of this feedback loop could potentially result in a situation of long-lasting successful commons management as described by Ostrom (1990).

Evidence that communication and rule development could solve the archetypical problem of overstocking on village pastures is provided by the results of the field experiments on pasture management conducted in the case study villages. The field experiments, in a setting with five players, reproduce the basic situation of the archetype. The effect of communication can be studied by comparing the treatments without and with communication for the indicators pasture quality, indicating the effect of total grazing intensity on the pasture, and payoffs, i.e., individual gains from stocking on the game pasture (Table 5).

The evidence confirmed that mutual communication significantly enhanced the capacity of players to avoid overstocking of their game pastures (I2, Table 5). Yet, the effect of communication differs between the Georgian and Azerbaijani case study villages, while the treatment without communication shows no significant difference between countries. The effects of communication are particularly high in Georgia as visible in higher payoffs and considerably improved pasture quality once participants were able to communicate. For the Azerbaijani cases, in the treatment without communication the number of pastures of good quality is higher than in the Georgian cases because of comparatively 
lower stocking intensities, indicating a higher awareness of the danger of pasture degradation from the real situation and comparatively careful stocking decisions. Because age and gender of the participants were not significantly different between the country groups, a direct influence of these factors can be ruled out. As indicated by the questionnaire accompanying the field experiments, in Azerbaijan coordinated and strategic approaches were chosen from the very beginning in the treatment without communication. However, when communication was possible, players of the Azerbaijani villages showed more often individualistic approaches, i.e., strategies were discussed but finally not executed because no mutual agreement was found or individual players exhibited free-riding behavior. The effect of communication was particularly low in Keremli and Plankend. In contrast, in Georgian case study villages players were claiming not having had a strategy but that they were reacting to the strategies of their coplayers as soon as communication was possible.

Thus, the game results indicate that case study villagers have a capacity and willingness for cooperation, although the effect of communication points to higher problem-solving capacities and mutual trust in the Georgian villages. The field experiments therefore support findings by other authors stating that communication enhances coordinated action and the capability to reach mutual agreement and cooperation (Ghate et al. 2013, Lopez and Villamayor-Tomas 2017).

Likewise, in reality, villagers in the case study villages with problems of overstocking engaged in discussions on how to develop rules to limit stocking rates as confirmed by interviews. In the case study village of Plankend, villagers already held village meetings to discuss the deterioration of their village pasture and made proposals on rule design, such as pasture resting. Also, villagers in Arashenda and Keremli discussed possible solutions aiming at rule designs, e.g., on rotational grazing, fencing, pasture care, the improvement of animal roads, etc., among each other. However, in none of the villages could inhabitants agree on changing the overall management of their pastures.

What is more, participant observation of the field experiments indicated a tendency to entrust decisions to one "leader" or "facilitator" (U5). This game observation, particularly for the Azerbaijani case study villages, was confirmed as also holding true for the lifeworld of villagers by the diverse statements during several workshops, where the necessity of having an actor take the lead on solving pasture management problems was addressed.

A factor particularly inhibiting self-regulation of pasture stocking rates are the lacking management rights of villagers over their village pasture in Georgia (GS1, GS4). Because there is no legal backing for rule development and implementation by villagers, the process is inhibited. Hence, discussions of pasture management in Georgian villages are often linked to the demand for official assignments of property rights prior to self-governance attempts on a local level. Thus, we emphasize that locally accepted types of informal or formal social leadership (internal leadership) and a supporting legal environment are additional high-leverage factors for solving the Tragedy of the Commons archetypical problem (Fig. 3).
Mobility as a way out? (Shifting the Burden archetype)

The Shifting the Burden archetype illustrates that short-term solutions to a problem often have side effects that exacerbate the original problem, while a long-term solution can only be achieved by a deeper understanding of the system. The archetype consists of two balancing feedback loops connected by a reinforcing feedback (Fig. 6): two balancing feedback loops represents a short-term fix (B1) and a possible long-term fix (B2), whereas the long-term fix is delayed through the negative influence of the reinforcing unintended consequence (Kim 2000b).

Fig. 6. The Shifting the Burden archetype applied to livestock mobility as the short-term fix for overstocking problems (red) and its solution by communication and rule design (blue).

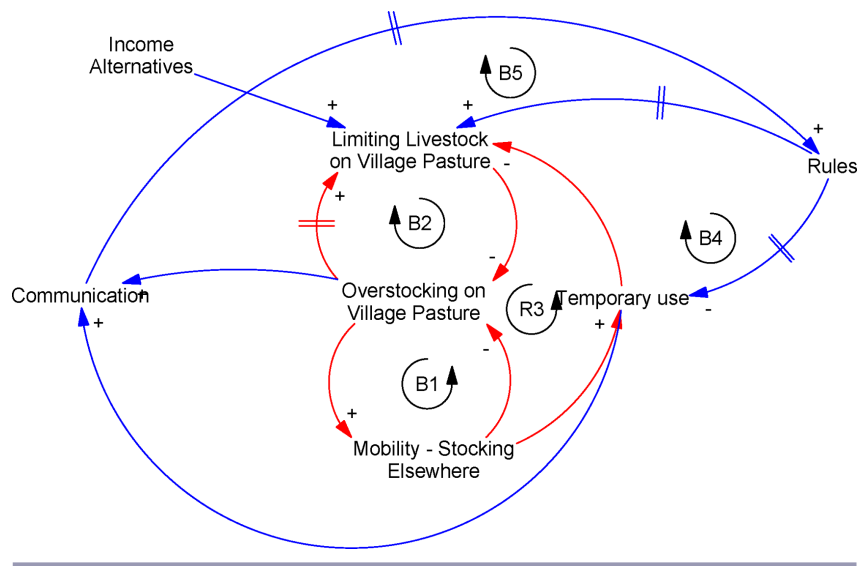

In the case study villages, these system dynamics apply to livestock mobility as a possible solution to overstocking on village pastures. As livestock numbers of villagers increase and the stocking rate exceeds the stocking capacity, villagers may decide to use other pastures with their livestock (RS3, U1, U2, RU5).

Figure 7 illustrates with survey data from the case study villages that village pastures are used by the overwhelming majority of sampled households in the case study villages, and thus represents the most important grazing resource (U8). Approximately $87 \%$ of them use the common village pasture for at least two months in a year. Only $10 \%$ of the investigated households use summer pasture and $7 \%$ winter pasture resources, whereas especially in Plankend the share of households using summer pastures is highest (ECO3). Keeping in mind that in Plankend the least pasture area per household is available (Table 1), this indicates a relation between livestock mobility and overstocking on village pastures. For Arashenda, this effect is not visible in the statistics for households in Figure 7 because a large share of the village livestock is kept in the mobile system by few households.

As confirmed in interviews with villagers, the decision to use other pastures, particularly during summer, depends on the fodder availability of the village pasture as well as the livestock holdings of the individual household (RS5, U1, U2). The scarce pasture area in Plankend virtually forces all households to switch to semimobile livestock keeping (Fig. 7, Table 1). Households with more than 300-500 sheep may be advised to use other pastures also in Keremli and Arashenda, which have a comparatively larger pasture area. Thus, livestock mobility in the short-term resolves 
Table 6. Rules for access and temporary use for mobile pastoralists in the case study villages.

\begin{tabular}{|c|c|c|c|c|c|c|}
\hline & \multicolumn{3}{|c|}{ Azerbaijani case study villages } & \multicolumn{3}{|c|}{ Georgian case study villages } \\
\hline & Atabey & Keremli & Plankend & Shakhvetila & Gombori & Arashenda \\
\hline $\begin{array}{l}\text { Mobile pastoralists from the village } \\
\ldots \text { can pass and rest for } 1-2 \text { days } \\
\ldots \text { can rest for several weeks } \\
\ldots \text { can use the village pasture during } \\
\text { summer }\end{array}$ & $\begin{array}{l}x \\
x \\
x\end{array}$ & $\begin{array}{l}X \\
X \\
x\end{array}$ & $\begin{array}{c}\mathrm{x} \\
\text { conflict }\end{array}$ & $\begin{array}{l}?^{\dagger} \\
?^{\dagger} \\
?^{\dagger}\end{array}$ & $\begin{array}{l}x \\
x \\
X\end{array}$ & $\frac{\mathrm{x}}{\mathrm{x}, \text { conflict }}$ \\
\hline $\begin{array}{l}\text { Mobile pastoralists from elsewhere } \\
\ldots \text { can pass the village pasture } \\
\ldots \text { can rest for } 1-2 \text { days during } \\
\text { migration } \\
\ldots \text { can stay in autumn for a few weeks } \\
\ldots \text { can use the village pasture during } \\
\text { summer }\end{array}$ & $\begin{array}{c}\mathrm{x} \\
\mathrm{x} \\
\mathrm{x} \\
\text { conflict }\end{array}$ & $\begin{array}{c}\mathrm{x} \\
\text { conflict }\end{array}$ & $\mathrm{x}$ & $\begin{array}{l}\mathrm{x} \\
\mathrm{x}\end{array}$ & $\begin{array}{c}\mathrm{x} \\
\mathrm{x} \\
\mathrm{x} \\
\mathrm{x}, \text { conflict }\end{array}$ & conflict \\
\hline
\end{tabular}

${ }^{\dagger}$ Insufficient data.

Fig. 7. Use of grazing resources by village households $(\mathrm{n}=$ 392).

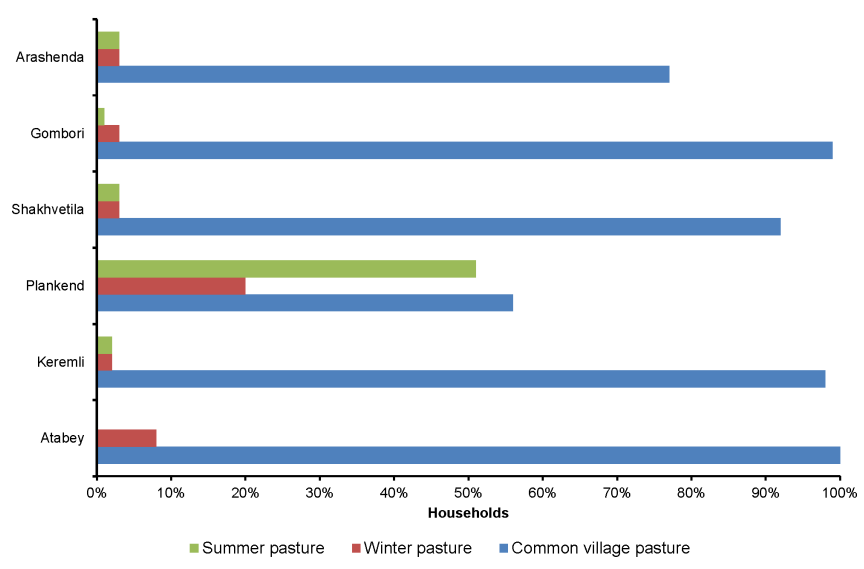

the initial problem of a high stocking rate by shifting grazing pressure to other pasture areas (B1).

Also in other villages in the region, increasing livestock numbers motivate livestock keepers to become mobile; in consequence this leads to an overall higher level of livestock mobility. Consequently, the increased mobility causes a higher stocking rate of summer and winter pastures until the point when these pastures also become overstocked and the regional pasture resources are reaching their capacity limits, which is indeed observed in Azerbaijan (Neudert et al. 2015). At that point, the short-term fix of shifting livestock grazing pressure to other pastures is not effective any more. In addition, increased livestock mobility and capacity limits on summer and winter pastures lead to an increased demand for temporary use on village pastures in autumn and spring. This causes additional pressure on the village pasture resources with even increased livestock numbers. At that point, the short-term fix hits back and worsens the original problem $(\mathrm{O} 2, \mathrm{R} 3$ in Fig. 6). That trespassing and resting on village pastures exacerbates overstocking on village pastures was also confirmed in interviews with villagers. Thus, this problem constellation is especially visible for the case study village Plankend, but also partly for Keremli and Arashenda as indicated by the perception of villagers, high stocking rates, and the contribution of stakeholder groups to the grazing pressure (Fig. $4)$.

A long-term fix would lie only in a limitation of stocking rates (B2). However, mobile livestock keepers tend to be even more sensitive to livestock number restrictions because for mobile farms to be economically profitable, economies of scale are required (delay mark in B2 in Fig. 6; Neudert and Allahverdiyeva 2009, Allahverdiyeva 2018). Thus, the long-term reduction of stocking rates is even more difficult to achieve with mobile livestock keeping.

\section{Solving the Shifting the Burden archetype}

Because villagers see that trespassing and resting exacerbates the problem of overstocking, they partly react with communication, e.g. complaints and discussions, and rule making to exclude mobile pastoralists from using their village pastures (GS5, B4 in Fig. 6). As shown by interviews, in all case study villages rules limiting the temporary use rights of mobile pastoralists can be observed. Villagers differentiate between mobile pastoralists resident in the village, who are part of the village community, and mobile pastoralists resident elsewhere (U4). In all villages, rights for mobile pastoralists resident elsewhere are less extensive compared to villagers' rights (Table 6). Rights are gradually restricted, obviously dependent on the perception of pasture scarcity; thus, least rights are held in the villages with least pasture resources (RS3). Communication and conflicts mostly occur on the most far-reaching right granted in the village (I2, I4).

However, the strategy of limiting use rights for mobile pastoralists also represents a "shift of the burden" to other pasture areas, and thus might be effective only as long as mobile pastoralists have possibilities to sidestep by using other village pasture areas in the vicinity. For solving the region-wide problem, a better regulation and clarification of property rights for pastoral migration routes would be required, which is only possible at the regional scale with participation of diverse stakeholder groups. 
Thus, the long-term solution of limiting livestock numbers should be pursued with increased efforts (B5). Discussions aiming at rule making to limit livestock numbers on a regional level are generally difficult and avoided at all costs by stakeholders. A high-leverage entry point would be to provide income alternatives for villagers, limiting their reliance on livestock keeping as an income source. In the workshops held in the case study villages, participants in all villages agreed that alternative income sources are a crucial point to solve overstocking problems and would be highly welcomed.

\section{Simultaneously occurring erosion and reforestation on the same} village pasture (Success to the Successful archetype)

The Success to the Successful archetype helps to understand diverging patterns (success or failure) as largely driven by internal forces of the system once an initial situation is established. The archetype consists of two reinforcing feedback loops representing alternative allocations of resources (Fig. 8). An initially higher allocation of resources to $\mathrm{R} 1$ reinforces this cycle, while an initially lower allocation of resources to $\mathrm{R} 2$ lead subsequently to a decline of resource allocation to that cycle (Kim 2000b).

Fig. 8. The Success to the Successful archetype applied to simultaneously occurring overuse and underuse of pasture plots (red) and solution by designing rules for pasture management and care (blue).

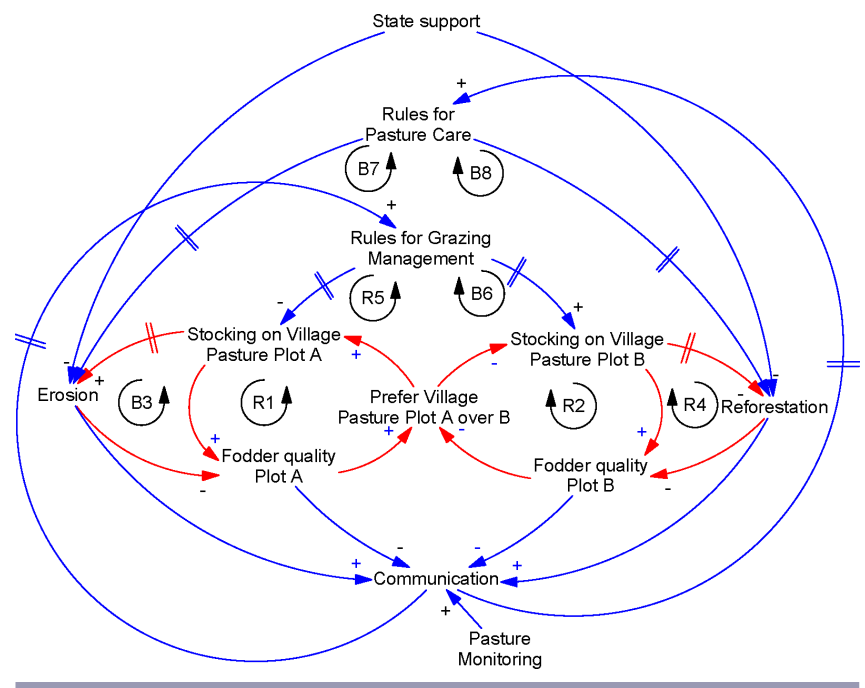

In the case study villages, these system dynamics can explain that overuse and erosion of some pasture plots coexists alongside with underuse and reforestation on other pasture plots on the same village pasture. Evidence for the existence of these problems is provided by the ecological investigations on pasture quality and the perception of villagers $(\mathrm{O} 2)$.

As shown in Figure 5, strong evidence for a low pasture quality was found particularly in the Georgian villages Gombori and Shakhvetila. Obviously, these differences in PDI values can be partly explained by more distinct erosion phenomena like the cover of erosion tracks (Fig. 9), which are particularly prevalent in Gombori and Shakhvetila. This might be partly because of a more rugged relief and the fact that on pastures with steeper slopes and thus a low SEI value (Table 3), like in Gombori and
Shakhvetila, browsing and trampling are likely to cause greater damages (RS9).

Fig. 9. Box-and-whisker plots of "Cover of erosion tracks" on $100 \mathrm{~m}^{2}$ in percent.

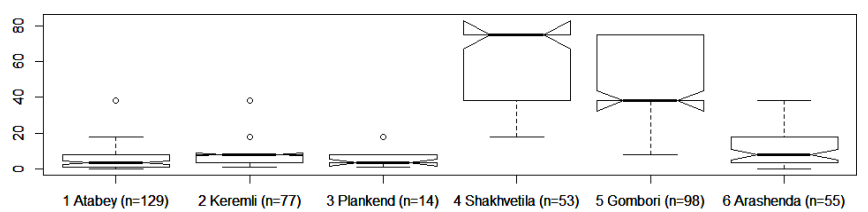

Moreover, on pastures with higher stocking rates the cover of the parameter sum of grazing indicator species is particularly high; generally, in Georgia these values are remarkably higher than in Azerbaijan (Fig. 10). The plots' coverage with grazing indicator species, e.g. thistles, thorny, or hairy plants, reflects the grazing intensity history, showing that a considerable grazing pressure in these villages existed over a longer time period.

Fig. 10. Box-and-whisker plots of "Sum of grazing indicator species" on $100 \mathrm{~m}^{2}$ in percent.

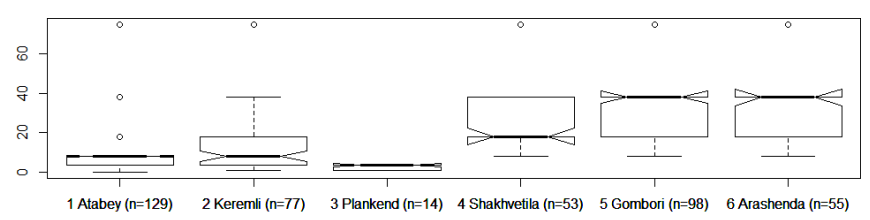

On the contrary, we find evidence for a higher cover of bushes (Fig. 11) especially for Gombori, Shakhvetila, and Keremli (partly also for Arashenda). This indicates that shrub encroachment processes are at work mostly with spiny bushes acting as pioneer species (RU3, Capistran Torres 2016). Because of shrub encroachment, the current pasture territory seems to be already significantly smaller than according to official sources. This is also confirmed by the perceptions on pasture quality by villagers.

Fig. 11. Box-and-whisker plots of "Bush and tree cover" on 100 $\mathrm{m}^{2}$ in percent.

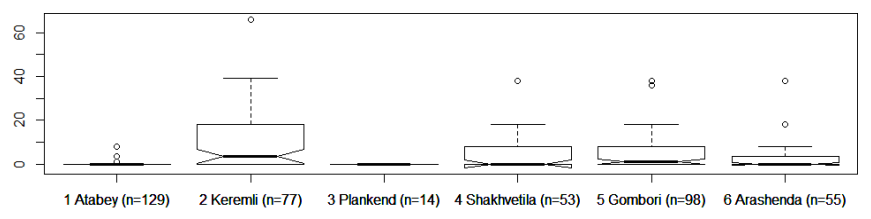

Thus, the evidence shows that erosion phenomena, high coverage of grazing indicators, and shrub encroachment exist on the same village pasture area, particularly in Gombori and Shakhvetila, but also in Arashenda and Keremli. This result is at first sight surprising.

The application of the archetypical processes can now explain the forces leading to these results: a low use pressure on one pasture plot leads to leftover standing biomass, particularly for less 
Table 7. Occurrence of village pasture management problem archetypes in the case study villages.

\begin{tabular}{|c|c|c|c|c|c|c|}
\hline \multirow{2}{*}{$\begin{array}{l}\text { Village pasture management } \\
\text { problems } \\
\text { (System archetypes) }\end{array}$} & \multicolumn{3}{|c|}{ Azerbaijani case study villages } & \multicolumn{3}{|c|}{ Georgian case study villages } \\
\hline & Atabey & Keremli & Plankend & Shakhvetila & Gombori & Arashenda \\
\hline $\begin{array}{l}\text { Overstocking on pastures } \\
\text { (Tragedy of the Commons) }\end{array}$ & & $\mathrm{X}$ & $\mathrm{XX}$ & & & $\mathrm{XX}$ \\
\hline $\begin{array}{l}\text { Mobility as a short-term solution for } \\
\text { overstocking } \\
\text { (Shifting the Burden) }\end{array}$ & & $\mathrm{X}$ & $\mathrm{XX}$ & & & $\mathrm{X}$ \\
\hline $\begin{array}{l}\text { Simultaneously occurring overused } \\
\text { and underused pasture plots } \\
\text { (Success to the Successful) }\end{array}$ & & $\mathrm{X}$ & & $\mathrm{XX}$ & $\mathrm{XX}$ & \\
\hline
\end{tabular}

Notes: XX: pronounced occurrence of this problem archetype; X: less pronounced occurrence of this problem archetype

palatable plants, and thus a lower fodder quality in the next year (RU7). Thus, livestock tends to avoid this plot (R2 in Fig. 8). Subsequently, on the underused plot reforestation occurs leading to a further decline of the fodder quality until the area is not useable for grazing any longer (R4). On the other hand, a high use pressure on other plots leads to a constant regrowth of fresh fodder and the suppression of grazing indicators, in consequence resulting in a higher use pressure by unmanaged livestock (R1). This might even lead to overuse of the respective area, as expressed by erosion and declining fodder availability of these plots (B3). A precondition for the dynamics of this archetype is that livestock is to a large extent left unmanaged or is only slightly managed (U9). The results of these dynamics are illustrated by the occurrence of strong erosion alongside a high cover of bushes as shown by the ecological investigations.

\section{Solving the Success to the Successful archetype}

In order to break up these dynamics, pasture management measures are necessary. This involves initial communication resulting from a dissatisfaction with the current situation and subsequently rule making on grazing management and pasture care measures (I2, I7). On the one hand, grazing management rules and conscious herding decisions are needed to establish a more even distribution of grazing pressure on the village pasture area (R5 and B6 in Fig. 8). On the other hand, pasture care measures can reverse and prevent reforestation on underused areas, and eventually technical measures and temporary grazing exclusion might be necessary to stop erosion in overused areas (B7 and B8).

As confirmed in the workshops, villagers in Gombori and Shakhvetila are already aware of the pasture management problems and engage in discussions (U7), however, internal rule making does not occur because of the unclear situation in property rights assignment (GS4). Villagers stress that machinery and knowledge needed for pasture care measures make the involvement of and investments by the regional administrations necessary (I6).

As a high-leverage entry point, a constant pasture monitoring might enhance the awareness of pasture management problems by all stakeholder groups (GS8). Currently, only a few rules on monitoring sustainable use by administrations are specified, and none of them was found to be implemented. In Azerbaijan, the
"Land Code" specifies that each land user is obliged to use land sustainably (No. 695-IQ, 25.06.1999, amendment 2.12.2008). Monitoring should be implemented by land inspectors in each district. However, according to the interviewed land inspectors no official routines on monitoring erosion and unsustainable use are available. Pasture condition is assessed by the villagers themselves mainly by rating the productivity and condition of livestock, while no traditional knowledge of monitoring vegetation and soil became apparent. In Georgia, agricultural extension centers located at the municipalities have advisory functions regarding sustainable management, but no cases of actual advice to the village population were observed. An easyto-apply monitoring approach, which could be used by villagers themselves, might also help them to make informed decisions about further grazing management and pasture care measures.

\section{Summarizing archetypical problems and solutions}

Occurrence of archetypical problems of pasture management in the case study villages

The three system archetypes helped to explain different recurring problems of village pasture management in the case study villages. As evident from the case study material, the problem dynamics occur only in some of the case study villages and can be more or less pronounced (Table 7).

In Table 7, overlaps and linkages between the three archetypical pasture management problems become apparent. Although each problem can be seen and explained separately, overstocking (Tragedy of the Commons archetype) and mobility as a shortterm solution (Shifting the Burden archetype) are clearly interlinked. The result of the first archetype, overstocking, is the starting point of the second archetype, and in their interaction, both archetypes result in increased problem dynamics. This aligns with the observation in Table 7 that both problem archetypes occur in three case study villages at the same time.

The third problem archetype, simultaneously occurring overuse and underuse, is apparently another problem dimension. Linked to intermediate stocking rates, this archetype may only occur when the Tragedy of the Commons and Shifting the Burden archetypes are less pronounced (as in Keremli) or absent (as in Shakhvetila and Gombori). Nevertheless, the obvious management failures point to similar root governance problems as in the Tragedy of the Commons archetype. 
Only in the case study village Atabey were none of the described problem archetypes found. The village has a comparatively large pasture area, where currently all village livestock, including livestock of resident semimobile pastoralists can graze without exceeding the stocking rate (Fig. 4), thus overstocking and mobility as short-term solutions for overstocking do not occur. At the same time, the grazing pressure seems to be distributed rather evenly, so that simultaneously occurring overused and underused pasture patches were not found. Thus, the village represents a case with low use pressure and a comparatively well managed pasture area characterized by the absence of problem archetypes.

The self-governance solution archetype

The solution presented for all three archetypical problems relies on a common abstract structure as presented in Figure 12. Typically, the problem archetype contains variables describing the behavior of actors (such as "A's Village Pasture Stocking" in Fig. 3, or "Stocking on Village Pasture Plot A" in Fig. 8) and performance measures (such as "Village Pasture Net Gain for A" in Fig. 3, or "Fodder quality on Plot A" in Fig. 8). These two variables describe the internal system dynamics in the archetypes (L1 in Fig. 12). The solution applied for all three archetypes builds on proposed self-governance: communication resulting from a dissatisfaction with performance measures initiates rule development intending to modify the behavior of actors (L2). Depending on the concrete formulation of behavior and performance variables polarity signs are added in the concrete solutions (Figs. 3, 6, and 8).

Fig. 12. Self-governance archetype as a solution to archetypical problem structures.

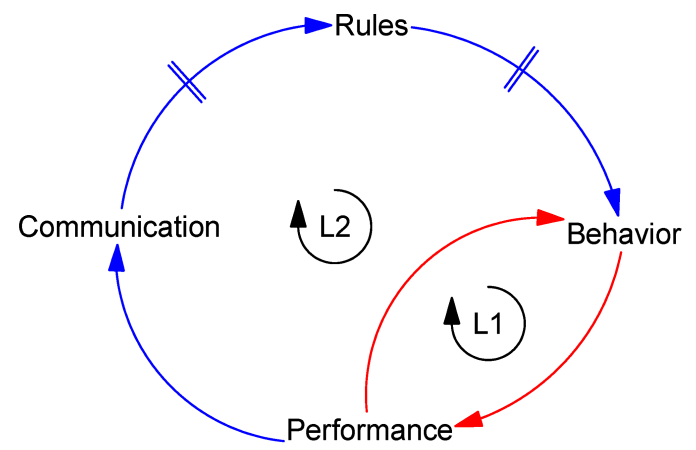

However, as illustrated by the case study material, communication does not always result in actual rule making, and even if rules are agreed upon, they do not always effectively influence behavior. For the Tragedy of the Commons archetype, we observed communication and attempts for rule making in several villages, but in none of them were effective rules designed. For the Shifting the Burden archetype, partly effective rules for the exclusion of mobile pastoralists were crafted, but the long-term solution, limiting livestock numbers, was not approached, yet. Thus, despite communication being a crucial condition for selfgovernance, the case studies particularly illustrate the challenges of rule design and enforcement.
Thus, additional measures should aim at shortening the delays between communication and rules or rules and behavior, respectively. As crucial high-leverage factors influencing the success of rule-making processes in the case study villages, we identified internal social leadership and a supporting legal environment (Fig. 3).

\section{DISCUSSION AND CONCLUSION}

In the preceding sections, we applied systems archetypes to explain recurring problems of village pasture management based on six case study villages in Azerbaijan and Georgia. We derived the archetypes of common village pasture management based on an iterative and multistep approach, which is recommended for system thinking and systems archetypes research (Luna-Reyes and Andersen 2003, Gharajedaghi 2011). For corroborating system dynamics, we mostly relied on the triangulation of data collected with different methods. Thus, the derivation relied on a qualitative approach often used in case study research (Yin 2003). However, in this study, no long-term historical data on the cases was available, although the temporal development of certain dynamics can be an indicator for the presence of archetypical dynamics (Kim 2000b). Instead, for investigating cause-effect relationships related to resource scarcity, we relied on a comparative case study approach by selecting the case studies to represent different levels of resource scarcity (Yin 2003). In a transdisciplinary approach, we included nonacademic knowledge and feedback from local stakeholders related to pasture quality and management. The chosen methodological approach is widespread in the system dynamics literature (Brzezina et al. 2017, Tenza et al. 2017) as well as in modeling approaches involving stakeholders (Castella et al. 2005, Lagabrielle et al. 2010), but goes beyond existing literature by engaging in an exceptionally holistic interdisciplinary analysis.

In the following, we assess how the archetypes of common village pasture management are linked to contextual factors and to each other. Furthermore, we discuss whether the archetypes found in the case study villages and their solutions are supported by other literature on pasture management.

Because the "pasture open to all" example describing the Tragedy of the Commons dynamics by Hardin (1968) is well known, the application of this archetype to pasture management problems suggests itself. Based on the underlying problem structure, this archetype rather represents a Tragedy of Open Access as pointed out by the work of Ostrom (1990). At first sight, the pastures in the case study villages also show many features of a common property regime because the user group, the village population, can be clearly delimited and, at least in Azerbaijan, holds management rights (Neudert, Theesfeld, Didebulidze, et al., unpublished manuscript). But, taking a closer look, crucial features of open access become apparent, such as the lack of regulation and limitation of stocking rates and the partly unregulated pasture access by mobile pastoralists. Thus, in the case study villages, the problem dynamics of this archetype are caused by a quasi-open access situation resulting from insufficiently specified rules of a collective use system. In the villages where the Tragedy of the Commons dynamics were not found, the number of households and livestock in relation to the pasture area is comparatively low, which is in line with theoretical considerations 
of property rights theory (Bromley 1991). Overstocking problems seem to be more frequent in the Azerbaijani compared to the Georgian cases, which is supported by other literature from the region (Didebulidze and Plachter 2002, Raaflaub and Dobry 2015, Neudert et al. 2015).

Mobility, as described in the second identified archetype, is a widespread strategy to reduce locally high grazing pressure in pastoral systems. It is mostly seen as an efficient way to use spatially and temporally heterogeneous fodder resources (Scoones 1994, Fernandez-Gimenez and Le Febre 2006). For the postsocialist regions of Central Asia, lacking mobility is often seen as the most urgent problem, resulting in overuse near settlements and underuse in remote regions (Robinson et al. 2012). A breakdown of pastoral mobility was also observed in the Caucasus region in the immediate transition period. However, contrary to countries like Kazakhstan, Kyrgyzstan, or Tajikistan, in Azerbaijan especially livestock mobility was reestablished comparatively quickly. Socioeconomic interests in livestock keeping have led to an unprecedented growth in livestock numbers (Neudert et al. 2015), leading also to high stocking rates in the mobile livestock keeping system and thus to the described problem dynamics. In Georgia, remote areas still remain underused, while in some areas overstocking can be noted (Didebulidze and Plachter 2002). Thus, the problem dynamics of the second archetype develop out of a local overstocking problem as described by the first archetype. The reinforcing feedback aggravating overstocking on village pastures is caused by the fact that migration routes for mobile pastoralists run through regions with sedentary livestock keeping. This competition between sedentary and mobile livestock keepers as well as overstocking of rangelands caused by economic and socio-demographic factors are also well-known problems from the African context (Basupi et al. 2017, Holechek et al. 2017, Tamou et al. 2018). Thus, although interrelations between grazing intensity and mobility are widespread in pastoral systems, whether the concrete problem dynamics of this archetype occur elsewhere in vertical pastoral mobility systems beyond the Caucasus region requires further investigation.

The archetypical problem of simultaneously occurring over- and understocking as described by our third archetype is at first sight counterintuitive: initially, enough grazing area is available, but the reinforcing internal dynamics lead to an unbalanced allocation of grazing pressure, and areas become unusable because of reforestation and erosion. That herbivores develop preferences for certain areas in spatially heterogeneous landscapes is well known from rangeland literature, leading to increased spatial heterogeneity in the landscape and the development of woodland pastures (Gillet 2008). Grazing selectivity was found to increase at lower stocking rates, with lower abundance of high-quality grazing areas and with rough terrain (von Müller et al. 2017, Töth et al. 2018). This corresponds well with our results because the archetype occurs mostly in villages with intermediate stocking rates, and effects on vegetation are most pronounced in villages with rough terrain. Negative effects, such as decreased quality and availability of fodder, were also predicted in modeling studies (Töth et al. 2018). Problems with heterogeneous distribution of livestock grazing despite moderate grazing intensities were noted earlier especially for Georgia (Didebulidze and Plachter 2002, Raaflaub and Dobry 2015; Gebhardt unpublished manuscript).
The patterns of occurrence of this problem archetype and its directly linked SES input variables shows that it represents a different problem dimension that does not show close linkages to the other problem archetypes. A main associated input variable is insufficient grazing management under moderate grazing intensities. Although the dynamics of selective grazing are well known to the rangeland literature, the consequences for pasture conditions as observed in the case study villages seem to be stronger than elsewhere.

The discussed interventions aim at identifying high-leverage factors for the solution of all archetypes of common village pasture management. The solutions of archetype one and two aim at establishing sufficiently specified rules for pasture use and measures to decrease grazing pressure. Because both problem dynamics are strongly interlinked, solutions should take them into account simultaneously, and several interventions need to be combined.

Changing the situation on village pastures into a comanagement between administrations and the local population would be one crucial factor. Besides communication and rule design, as mentioned in the solution archetype, other factors might play a role to make commons management effective (Ostrom 1990, Reid et al. 2014, Dörre 2015, Milupi et al. 2017). We especially stress leadership and the supporting legal environment recognizing the decision rights of villagers as hampering efforts to improve the Georgian situation. Social leadership and state recognition of property regimes have also been emphasized as important factors for successful commons management in the literature (Alden Wily 2018). However, focusing on village pastures alone is not appropriate because important parts of the system, the regional livestock mobility as described in the second archetype, would be ignored. Thus, in addition, regional governance structures should be strengthened to negotiate and clarify property rights with mobile pastoralists in a moderated, participatory process. Typically, pastoral SES involving mobility are governed by fuzzy or open access regimes, which nevertheless have the potential to be sustainable (Goodhue and McCarthy 2000, Behnke et al. 2016, Moritz et al. 2018). Hence, to further limit livestock numbers in the mobile system, other integral parts of that system, especially access to summer and winter pastures, need to be regulated so as to enhance sustainable use (Neudert 2015b). However, with the increasing size and diffuseness of the system, the solution archetype of self-governance is increasingly difficult to implement, and well-designed supporting state regulations, e.g., taxes and other market-based instruments, may have a relative advantage ( $\mathrm{Li}$ and $\mathrm{Li}$ 2012). In addition, to reduce the root cause of both archetypes, high livestock numbers, and economic needs, income alternatives and the economic development of rural areas should be supported.

Because the Success to the Successful archetype represents another problem dimension, solutions may be found relatively independently from the other two problem archetypes, but nevertheless linkages exist. Because grazing selectivity is strongly influenced by management and biotic factors (von Müller et al. 2017), our solutions aiming at enhancing grazing management and pasture care are in line with the rangeland literature. Improved knowledge on pasture condition through monitoring and enhanced grazing management might also be beneficial in 
case of overstocking problems. Changes in management should be discussed, implemented, and enforced within improved structures for local self-governance.

The solutions archetype, aiming to enhance self-governance in order to break up problem dynamics, is an abstracted, proposed archetype that potentially has validity for common-pool resource management beyond the case study region. In its structure it resembles explanatory models for the emergence of common-pool resource management (Ghorbani and Bravo 2016, Ghorbani et al. 2017). Although other potential solutions, e.g., the design and enforcement of externally designed rules or the privatization of common pastures, were discussed within the researcher team, we stress, in accordance with local stakeholders, local selfgovernance as a solution with high potential for sustainable development in the region. This might include nested governance structures across scales, e.g., for solving the Shifting the Burden archetype applied to regional livestock mobility. The proposed solutions also assign an important role to the state when it comes to establishing supporting governance structures, e.g., recognition of local level governance in Georgia or establishing knowledge and infrastructure for pasture monitoring. Moreover, in cases of severe pasture management problems, establishing selfgovernance would not offer an adequate solution. Additional substantial investments, e.g., in technical measures for erosion control or initial investments in pasture care, would then be needed. Thus, despite the fact that we see self-governance as the core measure of sustainable resource management in the region, we argue for careful design and adaption of measures to the local context (Acheson 2006, Ostrom and Cox 2010).

Case studies and modeling with stakeholder participation generally have their strengths in depicting case-specific processes and raising acceptance with stakeholders, while a general validity cannot be assumed (Castella et al. 2005). By applying the systems archetype approach to multiple, contrasting case studies, we attempted to identify recurrent patterns of pasture management problems with potential relevance for common pasture management in the Caucasus region and beyond. The archetype approach provided us with the opportunity to reach a middle level of abstraction and validity of the processes beyond the individual cases while avoiding an overgeneralization of processes (Oberlack and Eisenack 2018). The methodological approach led us to the identification of three archetypical processes describing the most prevalent problems in the six case study villages.

Examining the occurrence of three archetypes in six similar case studies allowed for a new perspective on the combination of archetypes across cases. System archetypes and other applications of the building-block approach to archetypes have explored the combination of several archetypical patterns in one case (e.g., Banson et al. 2016) or define archetypes as derived from multiple cases (e.g., Oberlack et al. 2016, Oberlack and Eisenack 2018). Yet, an explicit comparison of cases as shown in Table 7 allows for a deeper understanding of the linkages between archetypes. This analysis of interactions between archetypes can be extended further to analyze networks of archetypes, similar to Kimmich and Villamayor Tomas (2019).

However, the identified archetypical processes should be seen as proposals for archetypes, while the validity of these models beyond the present case needs to be tested with further data independent from the cases used for archetype derivation. In addition, further research is needed on the limits of validity for the archetypes. Fully validated archetypes might also provide potential for the transfer of policy approaches for sustainable pasture management as suggested in the solutions for archetypical problems (Eisenack 2012).

From a theoretical perspective we see great potential for further synergies in the simultaneous application of the SES framework and system archetypes. The SES framework focuses primarily on context factors influencing interactions and outcomes, whereas feedbacks and internal dynamics are formally integrated but seldom analyzed explicitly. In contrast, system archetypes focus nearly completely on internal dynamics while causal context factors are underemphasized. We argue similar to Trosper (2005) that it is necessary to take into account both contextual factors and internal dynamics to achieve a complete explanatory model for social-ecological systems. Beyond the application of system archetypes to social-ecological systems, a better conceptualization of context factors could also help to advance system archetype theory.

Responses to this article can be read online at: http://www.ecologyandsociety.org/issues/responses. php/10921

\section{Acknowledgments:}

This study was prepared for the project "Collective action and conflict on common village pastures - Comparative case studies in Azerbaijan and Georgia" (Co4). Financial support was provided by Volkswagen Foundation (Grant number 88 504). The study would not have been possible without the openness, support, and hospitality of many people in the case study villages. Besides the authors, many people contributed to the success of the project, particularly the PhD students M. Merabishvili, B. Imnadze, Z. Bregvadze, N. Mammadov, and S. Quliev, but also translators and assistants. We also thank the partners at State Agricultural University of Azerbaijan, Prof. M. Huseynov and Prof. $G$. Mammadov, and at the Agricultural University of Georgia, Prof. A. Didebulidze and Prof. T. Urushadze for their constant support of the project team. Valuable comments of two reviewers helped us to improve the manuscript significantly.

\section{LITERATURE CITED}

Aaltonen, K. 2011. Project stakeholder analysis as an environmental interpretation process. International Journal of Project Management 29(2):165-183. https://doi.org/10.1016/j. ijproman.2010.02.001

Acheson, J. M. 2006. Institutional failure in resource management. Annual Review of Anthropology 35:117-134. https:// doi.org/10.1146/annurev.anthro.35.081705.123238

Alden Wily, L. 2018. Collective land ownership in the $21 \mathrm{st}$ century: overview of global trends. Land 7(2):68. https://doi. org/10.3390/land 7020068 
Aliyev, B. 2007. Utilization of summer and winter pastures in Azerbaijan (Azərbaycanın yaya və qışotlaqlarının idarəolunması). Elm, Baku, Azerbaijan.

Allahverdiyeva, N. 2018 Wirtschaftliche Bewertung von Wanderschafhaltungsbetrieben in der Region Gandja-Gasach/ Aserbaidschan: Status quo und Ableitung von Verbesserungspotentialen. Kassel University Press, Kassel, Germany.

Atteslander, P. 2000. Methoden der empirischen Sozialforschung, de Gruyter, Berlin, Germany.

Bailey, K. D. 1978. Methods of social research. The Free Press, New York, New York, USA.

Banson, K. E., N. C. Nguyen, and O. J. H. Bosch. 2016. Using system archetypes to identify drivers and barriers for sustainable agriculture in Africa: a case study in Ghana. Systems Research and Behavioral Science 33(1):79-99. https://doi.org/10.1002/ sres. 2300

Bassett, T. J. 2009. Mobile pastoralism on the brink of land privatization in Northern Côte d'Ivoire. Geoforum 40(5):756-766. https://doi.org/10.1016/j.geoforum.2009.04.005

Basupi, L. V., C. H. Quinn, and A. J. Dougill. 2017. Pastoralism and land tenure transformation in Sub-Saharan Africa: conflicting policies and priorities in Ngamiland, Botswana. Land 6(4):89. https://doi.org/10.3390/land6040089

Behnke, R., editor. 2008. The socio-economic causes and consequences of desertification in Central Asia. Springer, Dordrecht, The Netherlands. https://doi.org/10.1007/978-1-4020-8544-4

Behnke, R., S. Robinson, and E. J. Milner-Gulland. 2016. Governing open access: livestock distributions and institutional control in the Karakum Desert of Turkmenistan. Land Use Policy 52:103-119. https://doi.org/10.1016/j.landusepol.2015.12.012

Benedetti, R., M. Bee, G. Espa, and F. Piersimoni, editors. 2010. Agricultural survey methods. Wiley, Chichester, UK. https://doi. org/10.1002/9780470665480

Bromley, D. 1991. Environment and economy - property rights and public policy. Blackwell, Oxford, UK.

Brzezina, N., K. Biely, A. Helfgott, B. Kopainsky, J. Vervoort, and E. Mathijs. 2017. Development of organic farming in Europe at the crossroads: looking for the way forward through system archetypes lenses. Sustainability 9(5):821. https://doi.org/10.3390/ $\underline{\text { su9050821 }}$

Capistran Torres, G. M. 2016. Patterns of shrub encroachment in the pastures of two Georgian villages. Thesis. University of Greifswald, Greifswald, Germany.

Cardenas, J.-C., M. A. Janssen, and F. Bousquet. 2008. Dynamics of rules and resources: three new field experiments on water, forests and fisheries. Pages 319-345 in J. A. List and M. K. Price, editors. Handbook on experimental economics and the environment. Edward Elgar, Cheltenham, UK. https://doi. org/10.4337/9781781009079.00020

Cardenas, J. C., J. Stranlund, and C. Willis. 2000. Local environmental control and institutional crowding-out. World Development 28(10):1719-1733. https://doi.org/10.1016/S0305-750X (00)00055-3
Castella, J. C., T. N. Trung, and S. Boissau 2005. Participatory simulation of land-use changes in the northern mountains of Vietnam: the combined use of an agent-based model, a roleplaying game, and a geographic information system. Ecology and Society 10(1):27. https://doi.org/10.5751/ES-01328-100127

Cox, M. 2014. Applying a social-ecological system framework to the study of the Taos Valley irrigation system. Human Ecology 42(2):311-324. https://doi.org/10.1007/s10745-014-9651-y

Cox, M. 2016. The pathology of command and control: a formal synthesis. Ecology and Society 21(3):33. https://doi.org/10.5751/ ES-08698-210333

Didebulidze, A., and H. Plachter. 2002. Nature conservation aspects of pastoral farming in Georgia. Pages 87-105 in B. Redecker, W. Härdtle, P. Finck, U. Riecken, and E. Schröder, editors. Pasture-landscapes and nature conservation. Springer, Berlin, Germany. https://doi.org/10.1007/978-3-642-55953-2 6

Dörre, A. 2015. Promises and realities of community-based pasture management approaches: observations from Kyrgyzstan. Pastoralism-Research Policy and Practice 5:15 https://doi. org/10.1186/s13570-015-0035-8

Eisenack, K. 2012. Archetypes of adaptation to climate change. Pages 107-122 in M. Glaser, G. Krause, B. M. W. Ratter, and M. Welb, editors. Human-nature interactions in the Anthropocene: potentials of social-ecological systems analysis. Routledge, New York, New York, USA. https://doi.org/10.4324/9780203123195

Eisenack, K., S. Villamayor-Tomás, G. Epstein, C. Kimmich, M. Magliocca, D. Manuel-Navarrete, C. Oberlack, M. Roggero, and D. Sietz. 2019. Design and quality criteria for archetype analysis. Ecology and Society, 24(3):06. https://doi.org/10.5751/ES-10855-240306

Ellis, F. 1988. Peasant economics - farm households and agrarian development. Cambridge University Press, Cambridge, UK.

Etzold, J., and R. Neudert. 2013. Monitoring manual for summer pastures in the Greater Caucasus in Azerbaijan GIZ Working Paper: Sustainable Management of Biodiversity, South Caucasus, GIZ, Bonn, Germany.

Fernandez-Gimenez, M. E., and S. Le Febre. 2006. Mobility in pastoral systems: dynamic flux or downward trend? International Journal of Sustainable Development and World Ecology 13 (5):341-362. https://doi.org/10.1080/13504500609469685

Freudenberger, K. S. 2008. Rapid rural appraisal and participatory rural appraisal: a manual for CRS fieldworkers and partners. Catholic Relief Services, Baltimore, Maryland, USA. [online] URL: https://www.crs.org/our-work-overseas/research-publications/ rapid-rural-appraisal-and-participatory-rural-appraisal

Gharajedaghi, J. 2011. Systems thinking: managing chaos and complexity: a platform for designing business architecture. Morgan Kaufmann, Amsterdam, The Netherlands.

Ghate, R., S. Ghate, and E. Ostrom 2013. Cultural norms, cooperation, and communication: taking experiments to the field in indigenous communities. International Journal of the Commons 7(2):498-520. https://doi.org/10.18352/ijc.376

Ghorbani, A., and G. Bravo. 2016. Managing the commons: a simple model of the emergence of institutions through collective 
action. International Journal of the Commons 10(1):200-219. https://doi.org/10.18352/ijc.606

Ghorbani, A., G. Bravo, U. Frey, and I. Theesfeld. 2017. Selforganization in the commons: an empirically-tested model. Environmental Modelling \& Software 96:30-45. https://doi. org/10.1016/j.envsoft.2017.06.039

Gillet, F. 2008. Modelling vegetation dynamics in heterogeneous pasture-woodland landscapes. Ecological Modelling 217 (1-2):1-18. https://doi.org/10.1016/j.ecolmodel.2008.05.013

Goodhue, R., and N. McCarthy. 2000. Fuzzy access: modeling grazing rights in Sub-Saharan Africa. Pages 191-210 in N. McCarthy, B. Swallow, M. Kirk, and P. Hazell, editors. Property rights, risk and livestock development in Africa. International Food Policy Research Institute, Washington, D.C., USA.

Hardin, G. 1968. The tragedy of the commons. Science 162:1243-1248. https://doi.org/10.1126/science.162.3859.1243

Hartel, T., N. Fagerholm, M. Torralba, Á. Balázsi, and T. Plieninger. 2018. Forum: social-ecological system archetypes for European rangelands. Rangeland Ecology \& Management 71 (5):536-544. https://doi.org/10.1016/j.rama.2018.03.006

Holechek, J. L., A. F. Cibils, K. Bengaly, and J. I. Kinyamario. 2017. Human population growth, African pastoralism, and rangelands: a perspective. Rangeland Ecology \& Management 70 (3):273-280. https://doi.org/10.1016/j.rama.2016.09.004

Kay, R. D., W. M. Edwards, and P. A. Duffy. 2012. Farm management. McGraw-Hill, New York, New York, USA.

Kerven, C., S. Robinson, R. Behnke, K. Kushenov, and E. J. Milner-Gulland. 2016. A pastoral frontier: from chaos to capitalism and the re-colonisation of the Kazakh rangelands. Journal of Arid Environments 127:106-119. https://doi. org/10.1016/j.jaridenv.2015.11.003

Kerven, C., B. Steimann, C. Dear, and L. Ashley. 2012. Researching the future of pastoralism in Central Asia's mountains: examining development orthodoxies. Mountain Research and Development 32(3):368-377. https://doi.org/10.1659/ MRD-JOURNAL-D-12-00035.1

Kim, D. H. 2000a. Systems archetypes II: using systems archetypes to take effective action. Pegasus Communications, Waltham, Massachusetts, USA.

Kim, D. H. 2000b. Systems archetypes III: understanding patterns of behavior and delay. Pegasus Communications, Waltham, Massachusetts, USA.

Kim, D. H., and V. Anderson. 1998. Systems archetypes basics: from story to structure. Pegasus Communications, Waltham, Massachusetts, USA.

Kim, D. H., and C. P. Lannon. 1997. Applying systems archetypes. Pegasus Communications, Waltham, Massachusetts, USA.

Kimmich, C., and S. Villamayor Tomas. 2019. Assessing action situation networks: a configurational perspective on water and energy governance in irrigation systems. Water Economics and Policy 05(01):1850005. https://doi.org/10.1142/S2382624X18500054

Lagabrielle, E., A. Botta, W. Daré, D. David, S. Aubert, and C. Fabricius. 2010. Modelling with stakeholders to integrate biodiversity into land-use planning - lessons learned in Reunion Island (Western Indian Ocean). Environmental Modelling \& Software 25(11):1413-1427. https://doi.org/10.1016/j.envsoft.2010.01.011

Lerman, Z. 2006. The impact of land reform on rural household incomes in Transcaucasia. Eurasian Geography and Economics 47 (1):112-123. https://doi.org/10.2747/1538-7216.47.1.112

Lerman, Z., and D. Sedik. 2010. Rural transition in Azerbaijan. Lexington Books, New York, New York, USA.

Li, S., P. H. Verburg, S. Lv, J. Wu, and X. Li. 2012. Spatial analysis of the driving factors of grassland degradation under conditions of climate change and intensive use in Inner Mongolia, China. Regional Environmental Change 12(3):461-474. https://doi. org/10.1007/s10113-011-0264-3

Li, W., and Y. Li. 2012. Managing rangeland as a complex system: how government interventions decouple social systems from ecological systems. Ecology and Society 17(1):9. https://doi. org/10.5751/ES-04531-170109

Lopez, M. C., and S. Villamayor-Tomas. 2017. Understanding the black box of communication in a common-pool resource field experiment. Environmental Science \& Policy 68:69-79. https://doi. org/10.1016/j.envsci.2016.12.002

Luna-Reyes, L. F., and D. L. Andersen. 2003. Collecting and analyzing qualitative data for system dynamics: methods and models. System Dynamics Review 19(4):271-296. https://doi. org/10.1002/sdr.280

McGinnis, M. D., and E. Ostrom. 2014. Social-ecological system framework: initial changes and continuing challenges. Ecology and Society 19(2):30. https://doi.org/10.5751/ES-06387-190230

Mee, L., P. Cooper, A. Kannen, A. J. Gilbert, and T. O'Higgins. 2015. Sustaining Europe's seas as coupled social-ecological systems. Ecology and Society 20(1):1. https://doi.org/10.5751/ es-07143-200101

Miles, M. B., and A. M. Huberman, 1994. Qualitative data analysis. SAGE, Thousand Oaks, California, USA.

Milupi, I. D., M. J. Somers, and W. Ferguson. 2017. A review of community-based natural resource management. Applied Ecology and Environmental Research 15(4):1121-1143. https://doi. org/10.15666/aeer/1504 11211143

Ministers' Cabinet of Azerbaijani Republic. 2000. Some juridical norm acts about the land code of Azerbaijani Republic according to judgement of Ministers' cabinet of Azerbaijani Republic Regulations on using and leasing of meadows and pastures (Azərbaycan Respublikasının Torpaq Məcəlləsi ilə bă̆lı bəzi normativ hüquqi aktlar haqqinda, Azərbaycan Respublikası Nazirlər Kabinetinin qərarı - Örüş, otlaq və biçənək sahələrinin istifadəyə və icarəyə verilməsi, habelə istifadə edilməsi qaydaları). Ministers' Cabinet of Azerbaijani Republic, Baku, Azerbaijani.

Moritz, M., R. Behnke, C. M. Beitl, R. Bliege Bird, R. M. Chiaravalloti, J. K. Clark, S. A. Crabtree, S. S. Downey, I. M. Hamilton, S. C. Phang, P. Scholte, and J. A. Wilson. 2018. Emergent sustainability in open property regimes. Proceedings of the National Academy of Sciences 115(51):12859-12867. https:// doi.org/10.1073/pnas. 1812028115 
Mushkelishvili, M., L. Mezvrishvili, B. Natsvlishvili, and M. Elizbarashvili. 2012. The role of social capital in rural community development in Georgia. Centre for Social Studies, Tbilisi, Georgia. [online] URL: https://www.researchgate.net/ publication/235218072 The Role of Social Capital in Rural Community_Development_of_Georgia

National Statistics Office of Georgia. 2017. Agriculture of Georgia 2016. National Statistics Office of Georgia, Tbilisi, Georgia.

Neudert, R. 2015a. Is individualized rangeland lease institutionally incompatible with mobile pastoralism? A case study from post-socialist Azerbaijan. Human Ecology 43:785-798. https://doi.org/10.1007/s10745-015-9792-7

Neudert, R. 2015b. Pasture use of mobile pastoralists in Azerbaijan under institutional economic, farm economic and ecological aspects. Dissertation, University of Greifswald, Germany. [online] URL: https://epub.ub.uni-greifswald.de/frontdoor/index/index/year/2015/ docId/1626

Neudert, R., and N. Allahverdiyeva. 2009. The economic performance of transhumant sheep farming in Azerbaijan and prospects for its future development. South Caucasian Annals of Agrarian Science 7(4):153-157.

Neudert, R., M. Rühs, and V. Beckmann. 2015. Implementation of pasture leasing rights for mobile pastoralists - a case study on institutional change during post-socialist reforms in Azerbaijan. International Journal of the Commons 9(2):648-669. https://doi. org/10.18352/ijc. 515

North, D. C. 1990. Institutions, institutional change and economic performance. Cambridge University Press, Cambridge, UK. https://doi.org/10.1017/CBO9780511808678

Notenbaert, A. M., J. Davies, J. de Leeuw, M. Said, M. Herrero, P. Manzano, M. Waithaka, A. Aboud, and S. Omondi. 2012. Policies in support of pastoralism and biodiversity in the heterogeneous drylands of East Africa. Pastoralism 2:14. https:// doi.org/10.1186/2041-7136-2-14

Nuthall, P. 2011. Analysis of farming systems. CABI, Wallingford, UK.

Oberlack, C., and K. Eisenack. 2018. Archetypical barriers to adapting water governance in river basins to climate change. Journal of Institutional Economics 14:527-555. https://doi. org/10.1017/S1744137417000509

Oberlack, C., D. Sietz, E. Bürgi Bonanomi, A. De Bremond, J. Dell'Angelo, K. Eisenack, E. C. Ellis, G. Epstein, M. Giger, A. Heinimann, C. Kimmich, M. T. J. Kok, D. Manuel-Navarrete, P. Messerli, P. Meyfroidt, T. Václavík, and S. Villamayor-Tomas. 2019. Archetype analysis in sustainability research: meanings, motivations, and evidence-based policy making. Ecology and Society, 24(2):26. https://doi.org/10.5751/ES-10747-240226

Oberlack, C., L. Tejada, P. Messerli, S. Rist, and M. Giger. 2016. Sustainable livelihoods in the global land rush? Archetypes of livelihood vulnerability and sustainability potentials. Global Environmental Change 41:153-171. https://doi.org/10.1016/j. gloenvcha.2016.10.001

Ostrom, E. 1990. Governing the commons: the evolution of institutions for collective action. Cambridge University Press, Cambridge, UK.
Ostrom, E. 2009. A general framework for analyzing sustainability of social-ecological systems. Science 325 (5939):419-422. https://doi.org/10.1126/science.1172133

Ostrom, E., and M. Cox. 2010. Moving beyond panaceas: a multitiered diagnostic approach for social-ecological analysis. Environmental Conservation 37(4):451-463. https://doi.org/10.1017/ $\underline{\mathrm{S} 0376892910000834}$

Ostrom, E., J. Burger, C. B. Field, R. B. Norgaard, and D. Policansky. 1999. Revisiting the commons: local lessons, global challenges. Science 284(5412):278-282. https://doi.org/10.1126/ science.284.5412.278

Parker, A. J. 1982. The topographic relative moisture index: an approach to soil-moisture assessment in mountain terrain. Physical Geography 3:160-168. https://doi.org/10.1080/0272364$\underline{6.1982 .10642224}$

Prediger, S., B. Vollan, and M. Froelich. 2011. The impact of culture and ecology on cooperation in a common-pool resource experiment. Ecological Economics 70(9):1599-1608. https://doi. org/10.1016/j.ecolecon.2010.08.017

Prusty, S. K., P. K. J. Mohapatra, and C. K. Mukherjee. 2014. System archetype to understand unintended behavior in Indian shrimp industry and to aid in strategy development. Systemic Practice and Action Research 27(4):97-416. https://doi. org/10.1007/s11213-013-9288-6

Raaflaub, M., and L. M. Dobry. 2015. Pasture management in Georgia. Swiss Agency for Development and Cooperation, Bern, Switzerland. [online] URL: https://www.eda.admin.ch/dam/ countries/countries-content/georgia/en/Pasture $\% 20$ Management $\%$ 20In\%20Georgia\%202015.pdf

Reid, R. S., M. E. Fernández-Giménez, and K. A. Galvin. 2014. Dynamics and resilience of rangelands and pastoral peoples around the globe. Annual Review of Environment and Resources 39:217-242. https://doi.org/10.1146/annurev-environ-020713-163329

Robinson, S., C. Wiedemann, S. Michel, Y. Zhumabayev, and N. Singh. 2012. Pastoral tenure in Central Asia: theme and variation in the five former Soviet Republics. Pages 239-274 in V. Squires, editor. Rangeland stewardship in Central Asia. Springer, Dordrecht, The Netherlands. https://doi.org/10.1007/978-94-007-5367-9 11

Salzer, A. K. 2016. Knowledge for sustainability - cultural capital of ethnic minorities in high mountain areas of the South Caucasus. Pages 127-156 in A.-K. Hornidge, A. Shtaltovna, and C. Schetter, editors. Agricultural knowledge and knowledge systems in post-Soviet societies. Peter Lang, Bern, Switzerland. https://doi. org/10.3726/978-3-0351-0857-6/16

Schwetz, H., I. Benischek, J. Mallaun, G. Krammer, R. Strassegger-Einfalt, and B. Swoboda. 2013. Einführung in das quantitativ orientierte Forschen und erste Analysen mit SPSS 19. Facultas, Vienna, Austria. ISBN: 978-3-7089-0957-8.

Scoones, I., editor. 1994. Living with uncertainty: new directions in pastoral development in Africa. Intermediate Technology Publications, London, UK. https://doi.org/10.3362/9781780445335

Senge, P. M. 2006. The fifth discipline: the art and practice of the learning organization. Random House, New York, New York, USA. 
Shatberashvili, N., I. Rucevska, H. Jørstad, K. Artsivadze, B. Mehdiyev, M. Aliyev, G. Fayvush, M. Dzneladze, M. Jurek, T. Kirkfeldt, and L. Semernya. 2015. Outlook on climate change adaptation in the South Caucasus mountains. United Nations Environment Programme, GRID-Arendal and Sustainable Caucasus, Nairobi, Kenya, Arendal, Norway, and Tbilisi, Georgia.

Sietz, D., U. Frey, M. Roggero, Y. Gong, N. Magliocca, R. Tan, P. Janssen and T. Vaclavik. 2019. Archetype analysis in sustainability research: methodological portfolio and analytical frontiers. Ecology and Society 24(3):in press.

Stroh, D. P. 2015. Systems thinking for social change: a practical guide to solving complex problems, avoiding unintended consequences, and achieving lasting results. Chelsea Green. White River Junction, Vermont, USA.

Tamou, C., R. Ripoll-Bosch, I. J. M. de Boer, and S. J. Oosting. 2018. Pastoralists in a changing environment: the competition for grazing land in and around the $\mathrm{W}$ Biosphere Reserve, Benin Republic. Ambio 47(3):340-354. https://doi.org/10.1007/ $\underline{\text { s13280-017-0942-6 }}$

Tenza, A., I. Pérez, J. Martínez-Fernández, and A. Giménez. 2017. Understanding the decline and resilience loss of a long-lived social-ecological system: insights from system dynamics. Ecology and Society 22(2):15. https://doi.org/10.5751/ES-09176-220215

Töth, E., B. Deák, O. Valkó, A. Kelemen, T. Miglécz, B. Tóthmérész, and P. Török. 2018. Livestock type is more crucial than grazing intensity: traditional cattle and sheep grazing in short-grass steppes. Land Degradation \& Development 29 (2):231-239. https://doi.org/10.1002/ldr.2514

Trosper, R. L. 2005. Emergence unites ecology and society. Ecology and Society 10(1):14. https://doi.org/10.5751/ES-01239-100114

Turner, B. L., V. Tidwell, A. Fernald, J. A. Rivera, S. Rodriguez, S. Guldan, C. Ochoa, B. Hurd, K. Boykin, and A. Cibils. 2016. Modeling acequia irrigation systems using system dynamics: model development, evaluation, and sensitivity analyses to investigate effects of socio-economic and biophysical feedbacks. Sustainability 8(10):1019. https://doi.org/10.3390/su8101019

Václavik, T., S. Lautenbach, T. Kuemmerle, and R. Seppelt. 2013. Mapping global land system archetypes. Global Environmental Change 23(6):1637-1647. https://doi.org/10.1016/j.gloenvcha.2013.09.004

Vidal Merino, M., D. Sietz, F. Jost, and U. Berger. 2018. Archetypes of climate vulnerability: a mixed-method approach applied in the Peruvian Andes. Climate and Development. https:// doi.org/10.1080/17565529.2018.1442804

von Müller, A. R., D. Renison, and A. M. Cingolani. 2017. Cattle landscape selectivity is influenced by ecological and management factors in a heterogeneous mountain rangeland. Rangeland Journal 39(1):1-14. https://doi.org/10.1071/RJ15114

Williams, K. W., and H. S. Tai. 2016. A multi-tier social-ecological system analysis of protected areas co-management in Belize. Sustainability 8(2):104. https://doi.org/10.3390/su8020104

Wolstenholme, E. 2004. Using generic system archetypes to support thinking and modelling. System Dynamics Review 20 (4):341-356. https://doi.org/10.1002/sdr.302
Yin, R. 2003. Case study research: design and methods. SAGE, London, UK.

Yu, L., and K. N. Farrell. 2013. Individualized pastureland use: responses of herders to institutional arrangements in pastoral China. Human Ecology 41(5):759-771. https://doi.org/10.1007/ s10745-013-9580-1 


\section{Appendix 1}

Table A1.1 Variables of the Social-Ecological Systems Framework (after Ostrom 2009) applied to common village pasture use

\begin{tabular}{|c|c|c|c|c|}
\hline \multirow[t]{2}{*}{ Variables } & \multirow{2}{*}{$\begin{array}{l}\text { Definition of variables for } \\
\text { common village pastures }\end{array}$} & \multicolumn{3}{|c|}{ Variables directly relevant for archetype...* } \\
\hline & & $\begin{array}{l}\text { Tragedy of the } \\
\text { Commons }\end{array}$ & $\begin{array}{l}\text { Shifting the } \\
\text { Burden }\end{array}$ & $\begin{array}{l}\text { Success to the } \\
\text { Successful }\end{array}$ \\
\hline RS Resource systems & Pasture & & & \\
\hline $\begin{array}{l}\text { RS1 Sector (e.g., water, forests, } \\
\text { pasture, fish) }\end{array}$ & Pasture & & & \\
\hline RS2 Clarity of system boundaries & $\begin{array}{l}\text { Administrative maps of pasture } \\
\text { area }\end{array}$ & & & \\
\hline RS3 Size of resource system & Size of pasture area & $A$ & A & \\
\hline RS4 Human-constructed facilities & Stables, water places on pastures & & & \\
\hline RS5 Productivity of system & Pasture fodder production & A & A & \\
\hline RS6 Equilibrium properties & $\begin{array}{l}\text { Coefficient of variation of } \\
\text { precipitation }\end{array}$ & & & \\
\hline RS7 Predictability of system dynamics & Seasonality of fodder supply & & & \\
\hline RS8 Storage characteristics & Seasonality, durability of grass & & & \\
\hline RS9 Location & $\begin{array}{l}\text { Altitude, distance of plots from } \\
\text { village }\end{array}$ & & & A \\
\hline RU Resource units & Fodder/Grass & & & \\
\hline RU1 Resource unit mobility & N/A & & & \\
\hline RU2 Growth or replacement rate & Fodder growth rate & $A$ & & \\
\hline RU3 Interaction among resource units & $\begin{array}{l}\text { Relative abundance of species, } \\
\text { reforestation }\end{array}$ & & & $A$ \\
\hline RU4 Economic value & Profitability of livestock keeping & & & \\
\hline RU5 Number of units & $\begin{array}{l}\text { Fodder supply, potential stocking } \\
\text { rate }\end{array}$ & A & $A$ & \\
\hline RU6 Distinctive markings & N/A & & & \\
\hline RU7 Spatial and temporal distribution & $\begin{array}{l}\text { Seasonality and spatial distribution } \\
\text { of fodder supply }\end{array}$ & & & A \\
\hline GS Governance system & Common use & & & \\
\hline GS1 Government organizations & $\begin{array}{l}\text { Administrations relevant for village } \\
\text { pastures }\end{array}$ & $\mathrm{S}$ & & \\
\hline GS2 Nongovernment organizations & N/A & & & \\
\hline GS3 Network structure & Neighborhoods, informal networks & & & \\
\hline GS4 Property-rights systems & $\begin{array}{l}\begin{array}{l}\text { Property rights for pasture } \\
\text { resource }\end{array} \\
\end{array}$ & $S$ & & S \\
\hline GS5 Operational rules & Rules on grazing and stocking & $A, S$ & $S$ & \\
\hline GS6 Collective-choice rules & $\begin{array}{l}\text { Rules on self-organization in } \\
\text { villages }\end{array}$ & & & \\
\hline GS7 Constitutional rules & Rules for self-administration & & & \\
\hline $\begin{array}{l}\text { GS8 Monitoring and sanctioning } \\
\text { processes }\end{array}$ & Pasture monitoring & & & S \\
\hline U Users & $\begin{array}{l}\text { Farm-Households and other } \\
\text { livestock keepers }\end{array}$ & & & \\
\hline U1 Number of users & Households, livestock & A & $A$ & \\
\hline U2 Socioeconomic attributes of users & $\begin{array}{l}\text { Socio-economic information on } \\
\text { households }\end{array}$ & A & A & \\
\hline U3 History of use & $\begin{array}{l}\text { Changes in land use in post- } \\
\text { socialist transition period }\end{array}$ & & & \\
\hline U4 Location & Village of origin of pasture users & & $\mathrm{S}$ & \\
\hline U5 Leadership/entrepreneurship & $\begin{array}{l}\text { Leadership with regard to pasture } \\
\text { use }\end{array}$ & S & & \\
\hline U6 Norms/social capital & $\begin{array}{l}\text { Social capital with regard to } \\
\text { pasture use }\end{array}$ & & & \\
\hline U7 Knowledge of SES/mental models & Knowledge on pasture condition & A & & $\mathrm{S}$ \\
\hline U8 Importance of resource & $\begin{array}{l}\text { Importance of pasture use for } \\
\text { livelihoods }\end{array}$ & A & A & \\
\hline U9 Technology used & Livestock management & & & $A$ \\
\hline I Interactions & $\begin{array}{l}\text { Pasture access, management and } \\
\text { cooperation }\end{array}$ & & & \\
\hline
\end{tabular}




\begin{tabular}{|c|c|c|c|c|}
\hline I1 Harvesting levels of diverse users & $\begin{array}{l}\text { Livestock possession per } \\
\text { household, mobility }\end{array}$ & & & \\
\hline I2 Information sharing among users & Communication & S & S & $\mathrm{S}$ \\
\hline I3 Deliberation processes & N/A & & & \\
\hline 14 Conflicts among users & Conflicts on pasture access and use & & $\mathrm{S}$ & \\
\hline I5 Investment activities & Investment in livestock & & & \\
\hline 16 Lobbying activities & $\begin{array}{l}\text { Influence of villagers on } \\
\text { administrations }\end{array}$ & & & $\mathrm{S}$ \\
\hline I7 Self-organizing activities & $\begin{array}{l}\text { Self-organization in pasture use, } \\
\text { rule design on pasture use in } \\
\text { villages }\end{array}$ & & & $S$ \\
\hline I8 Networking activities & N/A & & & \\
\hline O Outcomes & Sustainability of pasture use & & & \\
\hline \multirow{3}{*}{$\begin{array}{l}\text { O1 Social performance measures (e.g., } \\
\text { efficiency, equity, accountability, } \\
\text { sustainability) }\end{array}$} & Levels of cooperation & & & \\
\hline & Farm performance & $A$ & & \\
\hline & Equity measures & & & \\
\hline \multirow{2}{*}{$\begin{array}{l}\text { O2 Ecological performance measures } \\
\text { (e.g., overharvested, resilience, } \\
\text { biodiversity, sustainability) }\end{array}$} & $\begin{array}{l}\text { Pasture condition according to } \\
\text { ecological investigations }\end{array}$ & A & & A \\
\hline & $\begin{array}{l}\text { Pasture condition in the view of } \\
\text { pasture users }\end{array}$ & $A$ & $A$ & $A$ \\
\hline O3 Externalities to other SESs & Levels of mobile livestock keeping & & & \\
\hline $\begin{array}{l}\text { S Social, economic and political } \\
\text { settings }\end{array}$ & Background of Caucasus countries & & & \\
\hline S1 Economic development & $\begin{array}{l}\text { Economic development in } \\
\text { Azerbaijan and Georgia in post- } \\
\text { socialist transition }\end{array}$ & $A$ & & \\
\hline S2 Demographic trends & $\begin{array}{l}\text { Population and livestock number } \\
\text { development in Azerbaijan and } \\
\text { Georgia }\end{array}$ & $A$ & & \\
\hline S3 Political stability & Political systems & & & \\
\hline S4 Other governance systems & $\begin{array}{l}\text { Background of post-socialist } \\
\text { transition }\end{array}$ & & & \\
\hline S5 Markets & Markets for livestock products & & & \\
\hline S6 Media organizations & N/A & & & \\
\hline S7 Technology & N/A & & & \\
\hline ECO Related Ecosystems & Other pasture resources & & & \\
\hline ECO1 Climate patterns & Climate in case study villages & & & \\
\hline ECO2 Pollution patterns & N/A & & & \\
\hline ECO3 - Flows into and out of focal SES & $\begin{array}{l}\text { Other pasture resources on } \\
\text { regional level }\end{array}$ & & $A$ & \\
\hline
\end{tabular}

*: A: directly relevant for archetype, S: directly relevant for solution of the archetype 


\section{Appendix 2}

Table A2.1 Number of livestock and other socio-economic indicators in sampled households

\begin{tabular}{|c|c|c|c|c|c|c|c|}
\hline \multirow[t]{2}{*}{ Item } & \multirow[t]{2}{*}{ Unit } & \multicolumn{3}{|c|}{ Azerbaijani case study villages } & \multicolumn{3}{|c|}{ Georgian case study villages } \\
\hline & & Atabey & Keremli & Plankend & Shakhvetila & Gombori & Arashenda \\
\hline $\begin{array}{l}\text { Mobile and semi- } \\
\text { mobile households }\end{array}$ & $\mathrm{n}$ & 5 & 1 & 31 & 1 & 2 & 5 \\
\hline $\begin{array}{l}\text { Mean number of cattle } \\
\text { per household }\end{array}$ & heads/HH & 6.0 & 11.0 & 3.6 & 1.0 & 27.5 & 46.6 \\
\hline $\begin{array}{l}\text { Mean number of sheep } \\
\text { per household }\end{array}$ & heads/HH & 119.0 & 5.0 & 37.7 & 3.0 & 176.5 & 776.0 \\
\hline $\begin{array}{l}\text { Mean number of goats } \\
\text { per household }\end{array}$ & heads/HH & 8.2 & 4.0 & 2.9 & 0.0 & 4.5 & 11.0 \\
\hline $\begin{array}{l}\text { Mean number of } \\
\text { livestock per } \\
\text { household } \dagger\end{array}$ & $\mathrm{SU} / \mathrm{HH}$ & 163.2 & 75.0 & 62.3 & 9.0 & 346.0 & 1066.6 \\
\hline $\begin{array}{l}\text { Mean size of arable } \\
\text { land }\end{array}$ & ha/HH & 1.8 & 1.9 & 0.5 & 0.8 & 1.6 & 7.1 \\
\hline $\begin{array}{l}\text { Presence of non-farm } \\
\text { income sources }\end{array}$ & $\%$ of $\mathrm{HH}$ & 100 & 60 & 50.0 & 50 & 74.2 & 100 \\
\hline Sedentary households & $\mathrm{n}$ & 57 & 40 & 24 & 34 & 77 & 55 \\
\hline $\begin{array}{l}\text { Average number of } \\
\text { cattle per household }\end{array}$ & heads/HH & 3.9 & 9.1 & 1.3 & 7.5 & 3.4 & 5.9 \\
\hline $\begin{array}{l}\text { Average number of } \\
\text { sheep per household }\end{array}$ & heads/HH & 9.8 & 12.1 & 8.6 & 3.3 & 6.5 & 11.1 \\
\hline $\begin{array}{l}\text { Average number of } \\
\text { goats per household }\end{array}$ & heads/HH & 2.7 & 3.4 & 0.4 & 0.0 & 0.3 & 0.6 \\
\hline $\begin{array}{l}\text { Average number of } \\
\text { livestock per } \\
\text { household } t\end{array}$ & $\mathrm{SU} / \mathrm{HH}$ & 35.8 & 70.2 & 17.0 & 48.5 & 27.2 & 46.9 \\
\hline $\begin{array}{l}\text { Average size of arable } \\
\text { land }\end{array}$ & $\mathrm{ha} / \mathrm{HH}$ & 2.4 & 1.8 & 0.5 & 0.8 & 0.6 & 2.0 \\
\hline $\begin{array}{l}\text { Presence of non-farm } \\
\text { income sources }\end{array}$ & $\%$ of $\mathrm{HH}$ & 85.5 & 78.9 & 79.2 & 87.5 & 75.0 & 70.6 \\
\hline
\end{tabular}

+1 sheep unit (SU) is equal $50 \mathrm{~kg}$. 1 cow is 6 sheep.

$\mathrm{HH}$ : households 
Table A2.2 Actual stocking rate

\begin{tabular}{|c|c|c|c|c|c|c|c|}
\hline \multirow[t]{2}{*}{ Item } & \multirow[t]{2}{*}{ Unit } & \multicolumn{3}{|c|}{ Azerbaijani case study villages } & \multicolumn{3}{|c|}{ Georgian case study villages } \\
\hline & & Atabey & Keremli & Plankend & Shakhvetila & Gombori & Arashenda \\
\hline $\begin{array}{l}\text { Village households keeping } \\
\text { livestock }\end{array}$ & $\mathrm{HH}$ & 97 & 69 & 168 & 83 & 150 & 78 \\
\hline $\begin{array}{l}\text { Sedentary livestock } \\
\text { keepers }\end{array}$ & $\mathrm{HH}$ & 88 & 65 & 10 & 80 & 150 & 75 \\
\hline $\begin{array}{l}\text { Mobile and semi-mobile } \\
\text { livestock keepers }\end{array}$ & $\mathrm{HH}$ & 9 & 4 & 158 & 3 & 0 & 3 \\
\hline $\begin{array}{l}\text {... thereof: using village } \\
\text { pasture in summer }\end{array}$ & $\mathrm{HH}$ & 9 & 4 & 0 & 3 & 0 & 0 \\
\hline $\begin{array}{l}\text {... thereof: using village } \\
\text { pasture for stopover }\end{array}$ & $\mathrm{HH}$ & 0 & 0 & 79 & 0 & 0 & 3 \\
\hline $\begin{array}{l}\text { Mobile livestock keepers } \\
\text { from elsewhere passing } \\
\text { the village }\end{array}$ & herds & 10 & 50 & 55 & 25 & 10 & 10 \\
\hline $\begin{array}{l}\text {... thereof: resting on } \\
\text { village pasture }\end{array}$ & herds & 1 & 0 & 0 & 0 & 2 & 0 \\
\hline Actual stocking rate & SU/ha & 4.9 & 9.4 & 18.4 & 9.7 & 9.2 & 19.0 \\
\hline
\end{tabular}

SU: sheep unit, $\mathrm{HH}$ : households 